\title{
Desenvolvimento e desequilíbrio industrial no Rio Grande do Sul: uma análise secular evolucionária ${ }^{1}$
}

\author{
Marcelo Arend ${ }^{2}$ \\ Silvio Antonio Ferraz Cario $^{3}$
}

\begin{abstract}
Resumo
O presente artigo aplica as abordagens institucionalista e neoschumpeteriana para compreender a dinâmica de desenvolvimento industrial e a consequente evolução do desequilíbrio econômico do Rio Grande do Sul. A hipótese é que se originaram dois path dependencies, um dinâmico e outro não, determinados, amplamente, por fatores tecnológicos e pelas matrizes institucionais das duas "metades". Elementos, de larga duração, presentes no percurso original, como direitos de propriedade, aprendizagem, estrutura social, ideologia, hábitos, políticas públicas e inovações, produziram estruturas industriais locais e particulares, capazes de explicar a trajetória de desenvolvimento industrial e o desequilíbrio regional contemporâneo deste estado. A análise evolucionária mostra dois períodos cruciais para o entendimento do desenvolvimento industrial gaúcho: o começo da Primeira República e o início da segunda metade do século XX. Nesses dois momentos, a economia gaúcha encontrava-se em crise, vindo logo em seguida a reestruturar-se. A região responsável pela mudança tecno-produtiva, nos dois períodos, foi a Metade Norte, consolidando-se como matriz industrial dinâmica do Estado do Rio Grande do Sul.
\end{abstract}

Palavras-chave: Desenvolvimento industrial; Industrialização; Desenvolvimento econômico; Rio Grande do Sul; Desequilíbrios regionais.

\begin{abstract}
Development and industrial unbalance in Rio Grande do Sul: an evolutionary secular analysis

This present paper applies both the institutionalistic and neo-Schumpeterian approaches in order to understand the dynamics of industrial development and the consequent evolution of the economic unbalance of the State of Rio Grande do Sul. The hypothesis is that two path dependencies were originated, one was dynamic and the other was not. Such path dependencies were determined widely by technological factors and by the institutional matrix of the two "halves". Present in the original path, elements of long duration such as ownership rights, learning, social structure, ideology, habits, public policies and inovations, all produced local private industries, which explain the course of industrial development and the regional stability of this State. The evolutionary analysis shows two crucial periods for the understanding of the industrial development of Rio Grande do Sul: the beginning of the Old Republic and the beginning of the second half of the $20^{\text {th }}$ Century. In both those moments, Rio Grande do Sul's economy was going through a crisis, but soon afterward it was
\end{abstract}

(1) Trabalho recebido em outubro de 2008 e aprovado em março de 2009. Apresenta as principais conclusões de Arend (2004). Os autores agradecem as relevantes contribuições de um parecerista anônimo para a redação final do presente artigo.

(2) Professor Adjunto do Departamento de Ciências Econômicas da Universidade Federal de Santa Maria (UFSM), Santa Maria, RS, Brasil. E-mail: marceloarend@yahoo.com.br.

(3) Professor Associado II da Universidade Federal de Santa Catarina (UFSC), Florianópolis, SC, Brasil. E-mail: fecario@yahoo.com.br.

Economia e Sociedade, Campinas, v. 19, n. 2 (39), p. 381-420, ago. 2010. 
Marcelo Arend / Silvio Antonio Ferraz Cario

restructured. The Northern Half was the region responsible for the technoproductive change in both periods, thus consolidating itself as the dynamic industrial matrix.

Key words: Industrial development; Industrialization; Economic development; Rio Grande do Sul; Regional inequality.

JEL O10, O18, O33, R11.

\section{Introdução}

A partir da historiografia regional e de dados primários e secundários, o artigo procura apresentar uma "leitura" da evolução secular da indústria no território do Rio Grande do Sul a partir de insigths sugeridos pelas abordagens institucionalista e neoschumpeteriana. Ambas as abordagens atestam para o caráter evolucionário de questões econômicas e sociais e, neste artigo, servirão para sustentar a hipótese geral da constituição de dois path dependencies de longo prazo na dinâmica regional.

Dessa forma, o artigo trata de questões relacionadas à performance industrial, em longo prazo, de regiões de um mesmo Estado Federativo do Brasil. A abordagem utilizada para a análise é de cunho heterodoxo, distinta do receituário "dominante" da Ciência Econômica. A escolha por tal abordagem analítica deu-se pela preocupação de tratar o desenvolvimento industrial sob uma perspectiva evolucionária, na qual fatores de larga duração encontram respaldo e exercem influência relevante sobre o presente e o futuro. Assim, os fatores determinantes do desempenho econômico analisados podem sobreviver aos indivíduos e, sobretudo, influenciá-los presente e futuramente.

Trata-se, nesse contexto, de discutir de que maneira as instituições originam-se, evoluem e afetam o desempenho econômico, especialmente industrial, de determinada região. Os principais conceitos referem-se à dependência da trajetória (path dependence), à rigidez estrutural (lock-in) - tanto institucional como tecnológica -, a inovações, à aprendizagem, à cultura e ao enraizamento social (enbeddedness). Esses conceitos são determinados teoricamente, enquanto as condições de realidade que procuram expressar são determinadas localmente, a partir de estruturas socioeconômicas históricas. Com isso, interpretações a partir do marco teórico evolucionário atestam para a nãoconvergência e, inclusive, enfatizam que processos históricos de desenvolvimento econômico são essencialmente particulares. Nesses termos, dependendo de fatores históricos e de especificidades e idiossincrasias locais, uma região pode ser economicamente eficiente, enquanto a sua vizinha, não.

Para alcançar os objetivos propostos, faz-se necessária uma definição das duas regiões do Estado que ressalte o aspecto histórico da formação do Rio Grande do Sul pelo motivo da perspectiva evolucionária. Aqui, adotar-se-á a regionalização elaborada por Fonseca (1983), visto que, segundo o autor, "pode-se 
dividir o Estado [Rio Grande do Sul] entre 'norte' e 'sul', dadas as diferenças significativas entre ambas as regiões. Entretanto, a região 'norte' pode ser subdividida em duas zonas: a Serra e o Planalto". ${ }^{4}$ Tal visualização do Estado do Rio Grande do Sul, elaborada pelo autor, pode ser feita pela Figura 1.

Figura 1

Regiões do Rio Grande do Sul na Primeira República

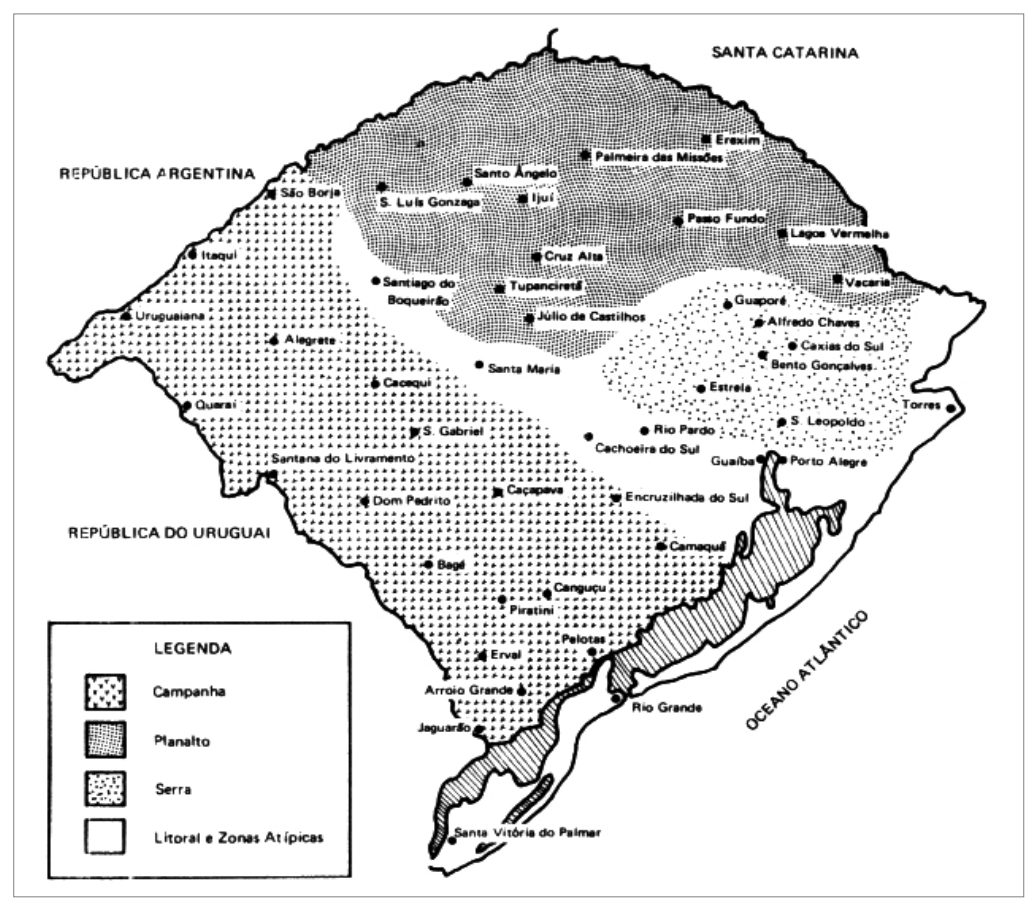

Fonte: Fonseca (1983, p. 28).

(4) A metade "sul", ou Campanha, é definida assim: "A Campanha é de antiga colonização ibérica; é onde, no Império, apareceu o trabalho escravo, principalmente nas charqueadas; durante o século XIX foi a mais importante região gaúcha, onde se desenvolveu predominantemente a criação de gado. É a zona das estâncias, de economia predominantemente pecuária onde aparecem o peão, o agregado e outras formas de parceria, todos vinculados ao latifúndio [...] Praticamente ela abrange todos os municípios gaúchos ao sul de uma linha que parte de São Borja, no oeste, indo até Camaquã, nas margens da Lagoa dos Patos. Os portos de Pelotas e Rio Grande vinculam-se à Campanha, sendo os grandes escoadouros da produção" (Fonseca, 1983, p. 27). Já a metade "norte" do Estado, que engloba duas sub-regiões (Serra e Planalto), é definida da seguinte forma: "A Serra é a região de colonização recente, sendo praticamente inexpressiva sua importância até meados do século XIX. Nela localizam-se os imigrantes europeus, principalmente alemães e italianos, todos recebendo pequenas extensões de terra. Nestas pequenas propriedades, a principal atividade econômica era a agricultura, não raro associada à criação de suínos. Na Serra quase não houve escravos, e predominava a mão-de-obra familiar. Assim, começou produzindo mais para consumo local que para exportação [...] O Planalto é também de recente ocupação, e abrange a região atualmente conhecida como Planalto Médio, o norte das Missões e os Campos de Cima da Serra [...] Economicamente, possui uma pecuária desenvolvida, ao lado da produção agrícola. Porém, localizando-se longe das charqueadas, em campos mais rudes, possui baixa capitalização e nela também o trabalho escravo pouco significância teve durante o Império" (Fonseca, 1983, p. 27-29). 
Uma divisão semelhante é adotada por Alonso e Bandeira (1994), mas nesta os autores definem região Norte, região Nordeste e região Sul. Essa divisão regional é aplicada a uma análise de longa duração, o que também vem ao encontro dos problemas abordados no presente estudo. Assim, ao longo do texto, quando "Metade Norte" for referida, entende-se a soma de participação regional da Serra e do Planalto (Fonseca, 1983), ou a soma da região Norte e da região Nordeste (Alonso; Bandeira, 1994). Já "Metade Sul" refere-se à região Sul (Alonso; Bandeira, 1994) ou Campanha (Fonseca, 1983). Em outros momentos, as duas metades também serão caracterizadas como subsistemas (colonial-imigrante e pecuário-charqueador), representando apenas sinônimos para as regionalizações acima definidas - o que ficará mais claro no decorrer do estudo. ${ }^{5}$

Alguns estudos seminais a respeito da problemática do desequilíbrio econômico sul-rio-grandense já lançaram certas hipóteses visando à explicação do referido fenômeno, porém a maioria o fez buscando somente o entendimento do atraso econômico do Sul do Estado. Bandeira (1994) confere a estagnação da região Sul aos seguintes fatores: predomínio do latifúndio e especialidade restrita a linhas de produção afins à bovinocultura tradicional. $\mathrm{O}$ autor, apoiado em Herbert Simon, atesta que os agentes econômicos do Sul teriam um comportamento satisficer. ${ }^{6}$

Alonso (1994) aplica a abordagem de Douglass North para a economia da Campanha gaúcha. No modelo de North (apud Alonso, 1994), contrapõem-se duas estruturas econômicas regionais, hipotéticas, bem distintas. Uma, caracterizada pelo predomínio de uma agricultura de plantation, em contraposição à outra, com a presença marcante de pequenas unidades agrícolas diversificadas. $\mathrm{O}$ autor conclui que a região caracterizada por grandes propriedades traria efeitos econômicos limitados a longo prazo. As grandes propriedades restringiriam o poder de crescimento econômico da região pelo surgimento de retornos decrescentes da atividade principal, pois a concentração tenderia a levar uma parcela considerável da população à exclusão da economia de mercado. A distribuição de renda desigual faria com que a parcela excluída da economia de mercado gastasse a maior parcela de sua renda com gêneros de primeira necessidade. Por outro lado, os latifundiários tenderiam a gastar seus rendimentos

(5) A elaboração de uma regionalização para o Rio Grande do Sul não é o propósito do presente estudo, o que demandaria elevado tempo e esforço. Assim, apesar de se utilizar, em alguns momentos, regionalizações distintas, o objetivo geral da análise não foi comprometido, pois o que se quer analisar é a evolução de um desequilíbrio amplamente evidenciado em ambas as regionalizações.

(6) Nas palavras do autor: "Os pecuaristas gaúchos seriam, portanto, na sua maior parte, satisficers, que preferiam uma rentabilidade mais baixa, porém segura, a enfrentar os riscos de perdas de capital implícitos nos investimentos necessários para a adoção de inovações tecnológicas caras ou para a introdução de linhas de produção alternativas" (Bandeira, 1994, p. 21). 
em importações de bens de luxo. Assim, a produção de manufaturados na região ficaria restringida e a região, a longo prazo, estagnaria. ${ }^{7}$

Recentemente, Monastério (2002) aplicou a abordagem do capital social para compreender o atraso econômico da região Sul do Rio Grande do Sul. A hipótese do autor é que a falta de capital social do tipo bridging e linking na região da Campanha gaúcha, derivada de sua formação socioeconômica, é a razão da sua decadência. Conforme seu estudo, as duas características específicas da formação econômica da região - a escravidão nas charqueadas e a criação de gado em uma região militarizada com alta concentração de terras - restringiram a acumulação de tais tipos de capital social e impediram a modernização econômica da Campanha durante a República Velha, determinando seu desempenho econômico a longo prazo. Monastério (2002) enfatiza também que o "Legado da Escravidão" faz-se presente hoje na Campanha. ${ }^{8}$

No que tange às interpretações a respeito do processo de desenvolvimento industrial sul-rio-grandense no contexto de constituição e desenvolvimento industrial nacional, o que se observa é que as análises da indústria gaúcha são feitas em períodos selecionados, conforme estudos que retratam a Primeira República, a inserção gaúcha no padrão de acumulação nacional das décadas de 1950 a 1970 e a de 1990. Na República Velha, então, destacam-se Fonseca (1983), Herrlein Jr. (2000) e Pesavento (1980). . Com relação ao período pós-1950,

(7) A aplicação dessa abordagem, como bem constatado por Monastério (2002), foca somente o lado da demanda, não dando destaque às questões de oferta. O modelo não esclarece, por exemplo, o que leva algumas regiões a inovarem em produtos e processos e realocarem recursos produtivos, nem ilustra como regiões com um setor dinâmico podem estancar o crescimento, como de fato ocorreu com a Metade Sul do Rio Grande do Sul. Monastério (2002) mostra, através de dados empíricos, que nas principais cidades do Sul do Estado - Pelotas e Rio Grande - em meados do século XIX, havia dezoito fábricas não relacionadas com o processamento de carne (fábricas de licores, chapéus, fundição, dentre outras), colocando em xeque a adoção de tal marco analítico.

(8) Embora o estudo de Monastério (2002) seja rico em dados para a explicação do atraso da Metade Sul, resta saber se apenas tal tipo de fator (capital social) pode desencadear uma estagnação secular em determinada região. Levar em consideração os padrões de acumulação nacional, o papel das políticas públicas, as características estruturais da indústria regional, estadual e nacional, a concorrência externa à região (tanto nacional quanto internacional) e os paradigmas tecnológicos ao longo da trajetória parecem ser aspectos relevantes para uma análise de desequilíbrio regional, pois assim não se peca ao pensar a região em estudo isoladamente, imune a estímulos externos.

(9) O estudo de Fonseca (1983) revela uma característica inovadora de análise, visto que apresenta integradamente aspectos relevantes da história, da política e da economia sul-rio-grandense no período 18901930. O estudo refere-se à política econômica levada a efeito pelo governo gaúcho e sua influência sobre a economia e política estaduais. Retrata, especificamente, o conflito entre governo ("chimangos") e oposição ("maragatos"). Além disso, o autor também buscou delimitar o espaço regional na análise, demarcando as regiões gaúchas que participaram do processo socioeconômico-político estadual no referido período, conforme apresentamos anteriormente. Na tese de Herrlein Jr. (2000a), o desenvolvimento econômico sul-rio-grandense no período 1889-1930 foi reinterpretado como não-periférico, alternativo e distinto do modelo de desenvolvimento capitalista que se estabeleceu nas regiões cujo dinamismo vinculava-se à agroexportação para o mercado mundial. Pesavento (1985 e 1988) fez uma análise ampla da economia pecuária, dando destaque para os criadores, charqueadores e frigoríficos, bem como aponta elementos do desenvolvimento industrial do Rio Grande do Sul. 
ocorreu um extenso debate a respeito da denominada "crise da economia gaúcha". Foram elaboradas várias interpretações sobre o processo histórico de integração da economia do Rio Grande do Sul à nacional, intensificado a partir de $1955 .{ }^{10} \mathrm{Na}$ década de 1990, os principais estudos que retratam a indústria gaúcha focalizam o processo de reestruturação ocorrido no período. ${ }^{11}$

Desse modo, verifica-se que não há estudos que demonstrem a dinâmica de desenvolvimento industrial regional em um processo evolutivo. Para além dessas visões mencionadas, o presente artigo visa lançar uma nova proposta para o entendimento do processo de desenvolvimento industrial regional sul-riograndense e do consequente desequilíbrio econômico regional que evoluiu ao longo do século $\mathrm{XX}$. Considera-se que as teorias institucionalista $\mathrm{e}$ neoschumpeteriana (evolucionistas), por serem complementares e levarem em consideração os aspectos históricos, as instituições específicas de cada região e a dinâmica econômica, podem contribuir para o melhor entendimento da dinâmica de desenvolvimento industrial e do desequilíbrio econômico, inerentes à economia gaúcha. Assim, entendemos que as instituições e suas práticas (compreendendo leis, cultura, hábitos, regras de conduta e o Estado) e a dinâmica capitalista (ambiente concorrencial e tecnologia) podem determinar trajetórias particulares de desenvolvimento econômico.

Parte-se da hipótese fundamental de que, para explicar a dinâmica da trajetória de desenvolvimento industrial particular do Rio Grande do Sul no contexto nacional e o consequente desequilíbrio regional, é necessário entender que muitas especificidades manifestas em sua formação instituíram uma estrutura industrial distinta ao modelo nacional - estrutura essa que perpetuou ao longo do século XX, apesar do atrelamento ao padrão de acumulação nacional, corroborando certo enraizamento (embeddedness) industrial regional. Parte-se do princípio de que, durante a Primeira República (período em que se materializa o capitalismo no Rio Grande do Sul), as duas regiões consolidaram bases

(10) Nas diferentes visões sobre as origens da crise da economia gaúcha, resultante de sua inserção no processo de integração econômica nacional, encontram-se causas exógenas e endógenas para sua perda de participação percentual na produção industrial nacional. Os principais estudos que retratam esse tema são: Oliveira (1960) que faz uma análise político-econômica do período, evidenciando principalmente o papel marginal que coube ao Rio Grande do Sul no bloco de investimentos do Plano de Metas, do Governo JK; Accurso et al. (1965), constatando que a crise tem origem em fatores internos, ou endógenos, a economia gaúcha; FEE (1976), apontando que o processo de integração é interpretado como um processo de subordinação; e FEE (1983), ao explicar a crise pela intensificação da concorrência intrarramo que resultou em diferenciais de crescimento entre regiões.

(11) Dentre os principais estudos destaca-se o realizado por Castilhos e Passos (1998), no qual afirmam, de forma geral, que três elementos influenciam sobremaneira o desempenho da indústria gaúcha no novo padrão de acumulação da década de 1990: sua forte integração com o setor primário, sua vinculação com a indústria brasileira de bens finais do complexo metal-mecânico e a integração dinâmica dos principais complexos industriais regionais. 
institucionais (econômicas, políticas e culturais) e técnicas distintas, que condicionaram o desempenho industrial de ambas e o próprio desenvolvimento industrial estadual ao longo do século XX. Assim, acredita-se que se originaram, no Rio Grande do Sul, dois path dependencies, um dinâmico e outro não, determinados amplamente por fatores tecnológicos e pelas matrizes institucionais, de cada região, presentes no percurso original, que produziram estruturas industriais particulares capazes de explicar o desequilíbrio regional contemporâneo.

Com o intuito de discutir o desenvolvimento e o desequilíbrio industrial do Rio Grande do Sul, o artigo está estruturado em seções. Inicialmente, apresenta-se a introdução com foco na problemática do estudo, hipótese de trabalho e elementos da revisão bibliográfica; na primeira seção são apresentadas as referências teóricas evolucionistas que servem de base para a análise do desenvolvimento industrial do Rio Grande do Sul; na segunda seção, discutem-se alguns fatos estilizados do desenvolvimento industrial do Rio Grande do Sul no século XX; na terceira seção, faz-se uma "leitura" do desenvolvimento secular da indústria gaúcha a partir dos insigths sugeridos pela abordagem evolucionista, destacando os direitos de propriedade na formação do Estado, o enraizamento social característico de cada região, a rigidez estrutural da região Sul, o catchingup tecnológico feito pela região Norte e, consequentemente, a trajetória dependente do passado de ambas as regiões; e, por fim, apresentam-se as principais conclusões do estudo.

\section{Integração de abordagens teóricas evolucionárias para análises de trajetórias de desenvolvimento econômico particulares}

Através das abordagens institucionalista e neoschumpeteriana, encontramos uma gama de princípios teóricos e analíticos que aceitam, de maneira generalizada, o fato das análises de realidades nacionais apresentarem especificidades. Isto posto, o que se quer enfatizar é a existência de trajetórias de desenvolvimento econômico diferenciadas. Caminhos, rotas e formas de desenvolvimento econômico dificilmente são compatíveis e comparáveis, pois, em cada país, região ou local ocorre a interação de uma série de fatores de natureza não só econômica, mas também social, política e cultural que, ao longo do tempo, moldaram-se de forma específica e única. ${ }^{12}$

O tratamento teórico da economia institucional não leva em conta o mercado como uma "ordem espontânea", mas sim como uma instituição

(12) Estas abordagens são referências interdisciplinares para a explicação dos processos de desenvolvimento econômico, uma vez que as modelagens formais teóricas fundadas no individualismo metodológico não conseguem captar, no mundo real e dinâmico, os fatores explicativos do desenvolvimento, bem como a razão das desigualdades existentes. 
socialmente construída. Neste enfoque, outras instituições são objeto de análise econômica: as transações, os contratos, as organizações, as leis, os costumes, as convenções, a tecnologia, o Estado, entre outras. As políticas públicas, os processos políticos e a evolução das instituições, bem como o próprio desenvolvimento econômico, são também parte do objeto de análise da economia institucional. Nesta perspectiva, a história assume relevância na medida em que a trajetória evolutiva considera, no âmbito temporal, as capacitações construídas, os processos de aprendizagem, as regras institucionais, os incentivos e as restrições a mudanças, etc. ${ }^{13}$

Também, posicionando de forma distinta do tratamento neoclássico - que considera a tecnologia exógena nos modelos de desenvolvimento -, a escola neoschumpeteriana considera a mudança técnica como centro do processo explicativo do desenvolvimento das firmas e marco para análises de desempenho econômico, e consequentemente para o entendimento dos desequilíbrios econômicos. Os processos de busca, rotinas, seleção e aprendizado, que cercam a atividade inovativa, ocorrem num ambiente dinâmico, incerto e diversificado, podendo conferir distintas trajetórias. ${ }^{14}$ Além disso, os neoschumpeterianos, mesmo centrados na mudança técnica, julgam importante o papel das instituições, visto elas poderem definir padrões ou trajetórias de desenvolvimento econômico distintos.

Assim, numa visão institucionalista e neoschumpeteriana, deve-se levar em conta os aspectos históricos, políticos, sociais e econômicos num processo evolucionário. Dessa forma, pode-se conferir as diferentes performances econômicas de países, regiões e lugares à natureza de suas instituições e à sua capacidade de inovar. Sob esse espectro, as instituições de "hoje" sempre guardam fortes conexões com as de "ontem", por isso a importância da trajetória institucional (Nelson, 1995). ${ }^{15}$

(13) O "velho institucionalismo", cujo principal expoente é Thorstein Veblen, traz a mensagem de que fatores como estrutura institucional, relações de poder, hábitos de pensamento e cultura afetam o desempenho econômico. Análises econômicas devem atentar-se para especificidades locais, dada a heterogeneidade de instituições existentes. Também, é substituído o conceito de equilíbrio pelo processo evolucionário, no qual fatos acidentais e longínquos no tempo têm uma influência destacada para a evolução institucional. Assim, a abordagem utiliza-se intensamente de path dependence. A "nova economia institucional", na qual Douglass North afirma-se como principal autor das análises de desempenho econômico diferenciado, busca retomar o debate da importância das instituições. North aproxima-se da antiga abordagem institucionalista, destacando-se, em sua obra, a preocupação com o desempenho das economias no transcurso dos tempos e as especificidades locais. Novos conceitos foram incorporados ao ideário institucionalista, como a existência de custos de transação, limitações informais, regras formais, direitos de propriedade, aprendizagem, organizações e poder de barganha.

(14) A esse respeito, ver especialmente Nelson e Winter (1982).

(15) "Abstraindo a enorme diversidade de coisas que têm sido chamadas instituições, há várias questõeschave que se acredita qualquer teoria séria de evolução institucional deve referir. Uma é path dependency. As instituições de hoje quase sempre mostram fortes conexões com as de ontem, e frequentemente com as de um século atrás, ou antes" (Nelson, 1995, p. 82, grifo nosso). 
O que ajuda a esclarecer o fenômeno do desenvolvimento econômico é a dinâmica estabelecida no tempo entre instituições, mudança institucional e inovação. Geralmente, uma inovação requer um rearranjo institucional. Contudo, as instituições também podem motivar determinado arranjo a inovar, como é concordado pelos institucionalistas. Assim, o processo de desenvolvimento econômico é originado pelas instituições e pela mudança institucional, pois estas induzem às inovações tecnológicas, ou pelo inverso, já que inovações implicam mudança institucional.

Todavia, o fundamental a ser ressaltado é que não necessariamente haverá harmonia entre instituições e técnicas escolhidas, como também não haverá um único "resultado" possível para a relação entre estes dois elementos. Consequentemente, elas influenciam-se reciprocamente, ainda que não de forma determinística. Porém, isto não significa que qualquer combinação entre tecnologia e instituições seja possível (pelo menos com alguma estabilidade), mas sim que o leque de combinações factíveis é limitado. Assim sendo, as tecnologias não se adaptam da mesma forma a qualquer institucionalidade, sempre sofrendo adaptações para se ajustar a elas. Isso porque as tecnologias não se encontram apenas inseridas em um ambiente técnico - o que significaria um "vácuo" institucional -, mas também estão incorporadas a uma determinada sociedade, região ou país, com seus costumes, regras e leis (Strachman, 2002, p. 135). Com isso, desenvolvimento econômico pode ser visto como resultado da configuração das instituições que lhes dão sustentabilidade, pois as inovações provêm de determinados arranjos institucionais. ${ }^{16}$

O resgate da história para a melhor compreensão do processo de desenvolvimento econômico, presente nos estudos de North, é, portanto,

(16) Para o "velho institucionalismo", as escolhas tecnológicas são mais orientadas pelo poder e menos pela eficiência. A tecnologia rotineiramente serve ao progresso social e à melhoria das condições materiais de reprodução das sociedades. Por outro lado, as instituições tendem a ser um fator de inércia, quase sempre impedindo mudanças tecnológicas ou freiando-as de modo que suas consequências não possam ser plenamente aproveitadas, atrapalhando, assim, o progresso social. Logo, uma mudança técnica requer uma mudança institucional, sendo que a inovação só origina-se num específico arranjo institucional. É por isso que Veblen dava atenção especial à questão da colaboração humana. Existindo colaboração em determinado arranjo institucional, certamente as relações de poder não se sobreporiam à inovação, e o consequente desenvolvimento ocorreria. Dessa forma, instituições geram inovações, e inovações acarretam mudança institucional. Pressupostos semelhantes podem ser extraídos do novo institucionalismo do modelo de Douglass North. Segundo Abramovay (2001), para North o subdesenvolvimento consiste, antes de tudo, num ambiente social em que a cooperação humana inibe a inovação, apoia-se em vínculos hierárquicos localizados e bloqueia a ampliação do círculo de relações sociais em que se movem as pessoas. É exatamente por isso que North vê que o desenvolvimento não reside em dons naturais, na acumulação de riquezas, nem mesmo nas capacidades humanas, mas nas instituições, ou seja, nas formas de coordenar a ação dos indivíduos e dos grupos sociais. Nações em que o valor do conhecimento transmitiu-se ao conjunto da sociedade formaram culturas de valorização do trabalho e da inovação, ao contrário daquelas de tradição escravista, que se apoiam francamente na separação entre trabalho e conhecimento. 
fundamental; e isto implica que a história importa. A história da evolução das instituições servirá para o autor responder às seguintes perguntas: "Como explicamos a sobrevivência de economias com desempenho persistentemente baixo durante longos lapsos de tempo? [...] O que explica a sobrevivência de sociedades e economias caracterizadas por um mau desempenho persistente? [...] Por que persistem as economias relativamente ineficientes?" (North, 1995, p. 121122).

Segundo North (1995, p. 124), as economias são caracterizadas por serem formadas por mercados imperfeitos, dadas as dificuldades de se compreender um ambiente complexo, e por serem dinâmicas. Também, as instituições caracterizamse por apresentar retornos crescentes. Isso significa que, uma vez escolhido um caminho, há a atuação dos mecanismos autorreforçantes, conforme Arthur (1994), que fazem com que a matriz institucional fique locked in e seja path dependence. Assim, mesmo que as instituições existentes não sejam as mais eficientes para gerar desenvolvimento econômico, como há retornos institucionais crescentes, a tendência é que elas persistam. Haverá mudanças institucionais, mas, indiscutivelmente, a partir dos arranjos já constituídos. Uma vez criadas as instituições, os mecanismos autorreforçantes fazem com que as economias fiquem locked in em determinadas estruturas institucionais, mesmo que essas reforcem atividades improdutivas, impedindo o desenvolvimento de atividades produtivas que melhorem o seu desempenho.

A ligação do passado com o presente e o futuro é dada pela história e significa que as instituições apresentam características de path dependence. Mas, se instituições importam para a promoção do desempenho econômico, por que não se copiam ou se adotam as melhores instituições de economias que já "aprenderam" a promover o desenvolvimento econômico? A questão-chave é que o tipo de aprendizado que os indivíduos em uma sociedade adquiriram ao longo do tempo condiciona o desenvolvimento. E, como a natureza do processo de aprendizagem é local, o desenvolvimento econômico é particular e diferenciado entre regiões ou países. O tempo, neste contexto, implica não somente experiências e aprendizado atual, mas também a experiência acumulada de gerações passadas que está enraizada (embedded) na cultura.

De acordo com Conceição (2002), uma análise institucionalista de determinada realidade deve, essencialmente, levar em consideração a relação do país, região ou local com o paradigma tecnológico em vigor ou em formação; deve conter alguma reflexão sobre o padrão organizacional das firmas existentes (hierarquizado ou não); deve conter elementos que descrevam os custos de transação vigentes (que influem na estrutura de governança das firmas); e deve contemplar alguma descrição das formas institucionais vigentes. $\mathrm{O}$ autor salienta que não se quer com isso estabelecer uma "receita" para o arcabouço de uma 
investigação institucionalista, mas ressalta que alguns dos conceitos produzidos pelos "antigos institucionalistas", pela Nova Economia Institucional e pelos neoschumpeterianos são importantes contribuições para a compreensão de fenômenos locais.

Nesse sentido, uma análise evolutiva para o desenvolvimento econômico chega a uma alternativa interessante e útil, contra o dominante individualismo metodológico comum às análises econômicas. Um modelo evolutivo evidencia os processos de variabilidade, seleção e retenção de rotinas. A teoria evolucionista focaliza, com o auxílio da passagem do tempo, o desenvolvimento de rotinas, em lugar da resposta instantânea de mudanças ambientais. Essa teoria utiliza path dependence, como um processo histórico, para antecipar possíveis comportamentos de agentes econômicos (rotinas prévias e valores).

\section{Fatos estilizados do desenvolvimento industrial do Rio Grande do Sul no século XX}

A formação da indústria gaúcha e sua inserção nos ciclos da economia brasileira revestiram-se de certas particularidades. Primeiramente, em sua formação histórica, o Rio Grande do Sul caracterizou-se por um modelo de desenvolvimento "voltado para dentro", que se caracterizava como uma anomalia no contexto nacional anterior à década de 1930.

Novas interpretações, presentes sobretudo nos estudos de Targa (2003) e de Herrlein Jr. (2000), para o período que se segue logo após o fim do Império (1893-1930), sugerem uma mudança profunda na economia estadual no transcorrer dos anos, como resultado de uma ruptura política radical. Contrário ao padrão produtivo anterior especializado na pecuária tradicional e nas charqueadas, a política econômica estadual passou a intensificar a diversificação produtiva. $\mathrm{O}$ "novo" projeto político encabeçado pelo Estado positivista propunha uma ideologia na qual o Rio Grande do Sul deveria ser autossuficiente, no sentido de buscar reduzir sua dependência externa. Nesse sentido, o Partido Republicano Riograndense (PRR) buscou transformar a economia estadual através de um projeto que visava dotar o Estado de uma relativa autonomia econômica, pois praticamente durante o século XIX fora especializado em atividades extremamente ligadas à pecuária bovina. Desse modo, no decorrer do período em consideração, a estrutura produtiva do Estado do Rio Grande do Sul alterou-se intensamente, diversificando-se em termos de produção e ampliando suas relações capitalistas.

Essa mudança na forma de conceber a dinâmica do Estado favoreceu a economia das colônias (Metade norte), baseada na agropecuária familiar e com desdobramentos comerciais e industriais. Além do Estado positivista, surgem novos sujeitos sociais na economia estadual, tais como pequenos agricultores, empresários industriais e comerciantes, que articulam a economia das colônias 
com as cidades, principalmente a capital Porto Alegre. Mas cabe destacar que o Estado positivista, diferentemente da política do Império - que associava a expansão gaúcha ao progresso da pecuária bovina -, começou a incentivar também outras atividades, diversificando, assim, a matriz produtiva regional, onde a antiga classe dominante passou a perder hegemonia política e econômica (Targa, 2003; Herrlein Jr., 2000). ${ }^{17}$

O período da década de 1930 até meados do século XX caracteriza-se por uma fase de transição, na qual se destacam a perda de autonomia dos Estados Regionais e a ampliação do mercado interno nacional. Nessa nova dinâmica, receberam investimentos as atividades produtoras de bens de consumo nãoduráveis e bens de produção leves, ocorrendo algumas especializações locais (por municípios) no Rio Grande do Sul. Contudo, apesar da mudança no padrão de acumulação nacional, a economia gaúcha não apresentava alterações significativas no seu padrão de acumulação regional, conservando as atividades de beneficiamento agropecuário, majoritárias até a década de $1960 .{ }^{18}$

A consequência direta disso foi a ampliação do hiato industrial entre Rio Grande do Sul e São Paulo. ${ }^{19}$ No momento em que se materializou por completo a

(17) Com isso, as exportações de bens, oriundos do complexo colonial-imigrante (identificado aqui como a Metade Norte do Estado) apresentaram extraordinário crescimento, juntamente com as atividades ligadas ao mercado interno do Estado, como beneficiamento industrial de produtos agrícolas e práticas comerciais. O Censo de 1920 também indicava a existência, no Rio Grande do Sul, de estabelecimentos de bens de produção leves (metalurgia, mecânica, material de transporte, minerais não-metálicos, química), atividades essas emblemáticas no Estado dos imigrantes europeus, os quais tinham destaque na produção nacional. Todavia, apesar do progresso industrial, havia limites para o desenvolvimento contínuo, sobretudo devido ao mercado de trabalho, que apresentava uma oferta restrita de mão-de-obra industrial, e nas atividades ligadas à transformação do boi, que se deparavam com a superação tecnológica de seu produto típico (Herrlein Jr., 2000).

(18) Segundo Accurso et al. (1965), existia também uma certa impossibilidade para um crescimento virtuoso, dada a extrema articulação da indústria com o setor primário. Os autores indicam que a economia gaúcha apresentava problemas, pois existia uma rigidez na produção industrial devido à sua dependência ao setor primário. O setor primário comprometia o desempenho industrial por apresentar um esgotamento de sua base física, sem modificação na produtividade, e uma inflexibilidade da estrutura de propriedade agrária, altamente concentrada. Somam-se a isso os investimentos deste setor, nos quais, em geral, não prevalecia o critério reprodutivo, sendo grande a inversão em ativos tais como imóveis na capital. Portanto, evidenciava-se um problema estrutural, visto que a economia gaúcha tinha, em grande parte, uma estrutura agrária de propriedade concentrada e de fronteira esgotada, além de uma indústria fortemente dependente do setor primário, que não conseguia uma oferta elástica para seus produtos dada a baixa qualidade da matéria-prima agropecuária. Assim, identificava-se uma inflexibilidade do quadro institucional gaúcho.

(19) As comparações relativas entre RS e SP são recorrentes na historiografia sul-rio-grandense, servindo de base para indicar, principalmente, diferenciais de desempenho econômico entre os Estados. Em relação à participação dos parques industriais gaúcho e paulista, no período da "industrialização restringida", as diferenças aumentaram. Em 1939, o Rio Grande do Sul tinha 9,1\% da produção industrial nacional enquanto São Paulo tinha 40,7\%; em 1949, o hiato aumenta para $7,9 \%$ e $48,9 \%$; e, em 1959 , tem-se $7 \%$ e $55,6 \%$, respectivamente. São Paulo, no final da década de 50, já detinha mais da metade da produção industrial brasileira. Durante o período de $1947-54$, a indústria brasileira evoluiu a uma taxa anual de $8,8 \%$, e sua participação na renda interna passou de $18,7 \%$ para $21,2 \%$. Ao mesmo tempo, a taxa anual de crescimento da indústria gaúcha foi de $9,2 \%$ e a participação do setor secundário na renda interna elevou-se de 14,7\% para 17,5\% (FEE, 1976). 
integração do mercado nacional, a percepção de "crise na economia gaúcha” era visualizada pela ampliação do hiato industrial do Rio Grande do Sul em relação ao centro hegemônico de acumulação de capital no país (São Paulo), pois a maioria dos investimentos do Plano de Metas foi estabelecido na região Sudeste. ${ }^{20}$ A partir dos anos 50, com o Plano de Metas, iniciou-se a montagem de setores de maior complexidade tecnológica, como a implantação da indústria de bens de capital e de bens de consumo duráveis. No Brasil, a incorporação e a difusão de tecnologias mais modernas se deram por meio de constante busca de tecnologias estrangeiras.

A partir da metade do século XX, a estratégia da política industrial nacional foi o investimento direto de empresas estrangeiras em setores de bens de consumo duráveis, e investimento estatal em setores de maior maturação, visando, sobretudo, a construção de uma matriz industrial compatível com o paradigma fordista. Estabeleceram-se, assim, as bases da moderna industrialização nacional (Conceição, 2002).

Com a "crise da economia gaúcha", o Estado Regional voltou a exercer destaque para a transformação industrial gaúcha. Sua principal estratégia foi atrelar o Estado sul-rio-grandense aos "planos" de desenvolvimento da nação, garantindo investimentos para o rearranjo produtivo interno. Implantaram-se, no Rio Grande do Sul, estabelecimentos industriais característicos do padrão tecnoprodutivo fordista, vinculando-se, desde então, o Estado aos ciclos da economia brasileira. O papel do Estado Regional deu-se basicamente mediante pressões junto à União, no sentido de direcionarem-se investimentos para a reestruturação do parque industrial regional, semelhante à transformação que ocorria em nível nacional. ${ }^{21}$ Um bom exemplo foi quando o Rio Grande do Sul recebeu, após uma acirrada disputa política entre vários Estados interessados, o III Polo Petroquímico (Dalmazo, 1992). A ação do Estado Regional, no período pós-1955, estava,

(20) De fato, com a integração nacional ocorreu uma intensificação da concorrência entre indústrias que produziam o mesmo tipo de produto, o que resultou em diferenciais de crescimento entre regiões. Conforme FEE (1983), como a economia paulista havia reunido pré-condições históricas que possibilitaram aos capitais uma maior modernização, ela obteve, com a maior integração do mercado nacional, ganhos no sentido de market share e economias de escala. Com a integração, especialmente a rodoviária, a concorrência intrarramo provocou transferência de valor dentro do mesmo setor produtivo àqueles capitais mais modernos, com menor custo, dado um preço homogêneo devido à concorrência. Sobre a extensa discussão da "crise da economia gaúcha", veja: FEE (1976), obra intitulada "25 Anos de Economia Gaúcha"; FEE (1983), "A produção gaúcha na economia nacional"; Accurso et al. (1965), "Análise do insuficiente desenvolvimento do Rio Grande do Sul”; e Oliveira (1960), "Rio Grande do Sul: um novo nordeste".

(21) Quando se elegeu o governador Leonel Brizola (1959-62), o estilo do seu discurso culminou na Conferência de Florianópolis, realizada em 1961, reunindo o Presidente da República (Juscelino Kubitschek) e os Governadores do Rio Grande do Sul, Santa Catarina e Paraná. O então governador denunciou a situação marginal em que se encontrava a indústria, a agricultura e a infraestrutura sul-rio-grandense em razão da discriminação feita pelo governo federal de Juscelino (Dalmazo, 1992).

Economia e Sociedade, Campinas, v. 19, n. 2 (39), p. 381-420, ago. 2010. 
portanto, em concordância com o Estado Nacional, no sentido da industrialização. Tal atitude repercutiria na indústria regional já na década de 1960, pois, a partir desta data, constata-se que a economia gaúcha sobrepuja sua crise e vincula-se ao novo padrão de acumulação nacional.

Atualmente, a estrutura industrial do Estado gaúcho assemelha-se à do país, porém apresenta algumas especificidades resultantes de sua trajetória pelo século XX. Há uma maior participação de indústrias tradicionais, em relação à média nacional, além da existência de significativas aglomerações produtivas, especializadas em determinados gêneros por municípios. ${ }^{22}$

Todavia, embora o Rio Grande do Sul consiga reestruturar seu parque industrial, tendo, a partir da década de 1960, uma participação interna maior de bens típicos do paradigma tecno-produtivo nacional, o esforço de modernização industrial não foi homogêneo dentro do Estado, ainda que mediante a participação do Estado Regional.

Neste contexto, procura-se demonstrar, na seção seguinte, que apenas uma região do Estado gaúcho conseguiu vincular-se ao modelo de industrialização capitalista brasileiro do pós-guerra. Com isso, a evolução da disparidade econômica regional foi determinada pelo próprio processo de desenvolvimento industrial do pós-1950, em consonância com o paradigma tecno-produtivo nacional. A região que se inseriu nessa nova dinâmica efetivamente participou das fases de crescimento da economia brasileira. No novo padrão de acumulação, construiu-se uma estrutura industrial concentrada na Metade Norte do Estado, bastante diversificada e integrada, percebida pelo conjunto de cadeias produtivas e complexos industriais. No final da década de 1980, verificava-se a quase total ausência de segmentos produtores de bens "dinâmicos"23 na Metade Sul. O fato surpreendente é que a Metade Norte concentrava não só os ramos dinâmicos, mas também os "tradicionais", enquanto sua participação se mostra majoritária até em setores em que a Metade Sul foi, ou é, especializada. A diversificação produtiva da Metade Norte é extraordinária, não apresentando especialização em alguns setores

(22) Desenvolveram-se importantes especializações na estrutura industrial do Rio Grande do Sul, configuradas em aglomerações produtivas de empresas industriais, nas quais se formaram redes de empresas - de maneira especial de pequeno e médio portes -, fornecedoras de peças, componentes e insumos às fabricantes de produtos finais. Tais nichos de especialização, em nível estadual, influenciam sobremaneira o desempenho da indústria gaúcha. Exemplos são as aglomerações produtivas coureiro-calçadista, metal-mecânico, químico, moveleiro e agroindustrial.

(23) Em FEE (1983), entende-se por "ramos industriais dinâmicos", ou "novos", os grupos da Metalurgia, Mecânica, Material Elétrico e de Comunicações, Material de Transporte e Química. Os grupos industriais tradicionais ("antigos") são: Madeira, Couros e Peles, Têxtil, Vestuário e Calçados, Produtos Alimentares, Bebidas e Fumo. 
como na Metade Sul, pois produz praticamente todos os produtos industrializados da matriz industrial do Rio Grande do Sul (Arend, 2004). ${ }^{24}$

\section{Elementos evolucionistas para a compreensão do desenvolvimento industrial desequilibrado do Rio Grande do Sul}

Introduzir o instrumental analítico institucionalista e neoschumpeteriano na análise regional é relevante, sobretudo com o fim de identificar, a partir de fatores de larga duração, a assimetria de dinamismo econômico dos dois subsistemas regionais. Dessa forma, acredita-se compreender melhor a anteriormente descrita trajetória particular de desenvolvimento industrial regional, enfocando principalmente o desequilíbrio interno ocorrido nesse processo. Como atesta o enfoque evolucionista, deve ser dada ênfase impreterível à história.

\subsection{Definição de direitos de propriedade e embeddedness}

Segundo North (1995), o conceito-chave para entendermos a prosperidade é o de instituições eficientes. Todavia, um arranjo institucional de sucesso consecutivamente estará fundamentado em um sistema de direitos de propriedade bem definido. As instituições são essencialmente sistemas de incentivo em qualquer tipo de troca, e é justamente como sistemas de incentivo que estas se relacionam com os direitos de propriedade. Assim, quanto melhor definidos e mais garantidos forem os direitos de propriedade, mais eficientes serão as instituições como sistemas de incentivo ao desenvolvimento econômico. Logo, os direitos de propriedade são os direitos dos quais indivíduos apropriam-se de seu próprio trabalho e dos bens e serviços que possuem. O uso de tais direitos é uma função de normas legais, de organizações formais, de cumprimento obrigatório e de normas de conduta, ou seja, é o marco institucional (North, 1995).

No entanto, apesar dos direitos de propriedade apoiarem-se em direitos e sanções regulamentadoras, constata-se que não é apenas esse o ponto, pois também decorrem amplamente do costume e da tradição. É na relação complexa e evolutiva da relação entre características legais, formais e consuetudinárias (cultura), que o direito e a propriedade devem ser definidos (Hodgson, 1994, p. 170).

(24) Ao analisar o PIB industrial da Metade Sul, nota-se que, no período posterior a 1959, o declínio foi bastante significativo, chegando a se manter uma redução do produto industrial quase que constante. Recentemente, menos de $10 \%$ da produção industrial gaúcha foi realizada na Metade Sul e apenas um quarto da população do Estado residiu dentro desses limites. Para uma região que chegou a gerar $34,57 \%$ de toda a produção industrial do Rio Grande do Sul em 1939, alcançar uma participação de apenas 9,6\% em 2001 foi revelador da perda acentuada de dinamismo do seu parque industrial (Alonso, 2003). 
Considerando estes aspectos, cabe a pergunta: como se definiram os direitos de propriedade no Estado sul-rio-grandense? Para alcançar a resposta, é preciso recorrer à formação histórica do Rio Grande do Sul.

Inicialmente, em função do não-cercamento dos campos, o gado que se reproduzia livremente no Pampa induziu a formação de bandos armados preadores de gado - para sua disputa. Esses bandos, organizados "afazendavamse" na região meridional, sendo essa a origem da ocupação privada do território e basicamente a procedência das primeiras estâncias gaúchas. A Coroa Portuguesa, conhecedora dessa disputa local e motivada pela manutenção e expansão de seus territórios, estabeleceu fortes (quartéis) na região sul-rio-grandense e distribuiu títulos de propriedade aos preadores de gado, legalizando as denominadas estâncias. $^{25}$

Dessa maneira, no Brasil meridional, o clima recorrente de guerra e disputas fez com que a defesa das fronteiras contasse com os estancieiros, que eram líderes militares locais e peões que acumulavam a atividade de soldados. Freitas (1985) denomina-os de "empresários-guerreiros", apontando que o Rio Grande do Sul foi "a única porção do território brasileiro conquistada pelos próprios moradores, através de guerras contra uma potência europeia”. Os proprietários de terras caracterizavam-se por serem "empresários-guerreiros" porque, para adquirirem os títulos da Coroa portuguesa que legitimavam a propriedade, tinham, muitas vezes, de passar por guerras contra os castelhanos. ${ }^{26}$ O resultado foi a formação dos latifúndios pecuários presentes até hoje no Rio Grande do Sul, característicos da Metade Sul do Estado. A primeira concessão foi feita em 1732, e por volta de 1803 a Campanha gaúcha já estava totalmente repartida entre aproximadamente quinhentos (500) grandes proprietários. Acrescenta-se a isso a forma não democrática de distribuição das sesmarias. Quem

(25) A título de curiosidade, vale repassar o ciclo de guerras e os eventos mais significativos (e que não foram poucos) do século XIX, que afetaram sobremaneira o território gaúcho, compilados por Targa (1996, p. 20): * 1811-14, José Artigas organiza a sublevação do Uruguai contra a Espanha, forças militares portuguesas e rio-grandenses invadem a Banda Oriental. * 1816, Artigas organiza a resistência contra os portugueses. * 1820, Artigas é derrotado e refugia-se no Paraguai, onde Francia é ditador desde 1814. * 1821, tratado entre Rio de Janeiro e Buenos Aires, pelo qual o território do Uruguai passa a fazer parte do Reino Unido de Portugal, Algarves e Brasil com o nome de Província Cisplatina. * 1822, recomeça a resistência no Uruguai. * 1828, independência do Uruguai. Em 1830, a Inglaterra, as Províncias Unidas do Prata (futura Argentina) e o Brasil reconhecem a existência da República Oriental do Uruguai. * 1835, início da ditadura de Rosas na Argentina. * 1835-45, os estancieiros do Rio Grande do Sul promovem uma guerra civil contra o Império (inicialmente federalista, depois separatista). * 1848-51, Guerra Grande onde o Brasil intervém no Uruguai apoiando caudilhos da oposição, com vitória brasileira. * 1851-2, o Brasil faz guerra à Argentina. * 1864-70, guerra do Brasil, e depois do Uruguai e da Argentina, contra o Paraguai de Solano Lopes.

(26) "Distribuíram-se as sesmarias (propriedades destinadas a estancieiros) - aos homens que haviam prestado serviços de certa relevância - merecedores de recompensas como militares, ou àqueles que dispusessem de recursos pecuniários suficientes para se instalarem como estancieiros e manterem o seu estabelecimento" (Cardoso, 1977). 
não possuísse propriedade, de acordo com a legislação portuguesa, não poderia receber sesmaria. (Cardoso, 1977; Targa, 1996; Monastério, 2002; Herrlein Jr., 2000). ${ }^{27}$

$\mathrm{Na}$ esteira da questão: a forma como foram definidos os direitos de propriedade na região da Campanha tenderia a estimular um desenvolvimento econômico por um longo período de tempo? Pelo analisado, a região Sul do Rio Grande do Sul foi constituída em um ambiente de guerra recorrente. Esse ambiente, reflexo não somente de uma instabilidade política entre dois Impérios uma vez que a Revolução Farroupilha (1835-1845) atesta que a elite local rebelouse contra a própria Coroa Portuguesa -, certamente ameaçava a garantia dos direitos de propriedade da região. Sendo as guerras rotineiras, o esperado era que se gerassem expectativas negativas sobre a posse do território, ou seja, poderia haver dúvidas sobre o domínio futuro dos direitos de propriedade. Do mesmo modo, muitos capitais externos à Campanha poderiam não enxergar incentivos para investir em tal ambiente institucional. ${ }^{28}$

A definição dos direitos de propriedade, maiormente sobre a posse da terra, afetaria a evolução secular da região no que se refere à concentração de riqueza. Entretanto, a definição dos direitos de propriedade também repercutiria sobre a natureza das relações sociais locais, revelando uma idiossincrasia específica à Campanha.

A posse de uma sesmaria constituía um poder econômico, social e político. Em torno do grande proprietário, reuniam-se os que trabalhavam sob suas ordens, os que necessitavam de sua proteção e, até mesmo, os que tinham medo de sua força (Roche, 1969; Urbim, 2003).

Raymundo Faoro (apud Araújo; Fischer, 1998) entende que esses "líderes" sul-rio-grandenses seriam caracterizados pelo sultanismo, estilo de dominação que, segundo Max Weber, move-se com a desenvoltura da tradição. Para Faoro, remetendo a análise aos tempos das guerras platinas de independência e das guerras de fronteira dos tempos coloniais,

(27) Se, por um lado, a estância representa a fixação à terra e o aproveitamento da riqueza pastoril, por outro, limitou a expansão do povoamento, na medida em que o estancieiro, proprietário de uma grande extensão de terras, ocupava apenas uma pequena área, deixando o restante inexplorado e em situação de abandono. Nesse sentido, a política de distribuição de sesmarias determinou um povoamento ralo e disperso (Lando; Barros, 1976, p. 48).

(28) Além disso, aqueles estancieiros já inseridos no meio poderiam estar mais certos de que seus direitos de propriedade seriam garantidos, em relação a agentes vindos de fora. Monastério (2002) ressalta - e este é o ponto - que estes últimos estariam mais propensos a serem expropriados do seu gado ou mesmo de sua terra, dada a ausência de uma estrutura institucional que protegesse os direitos de propriedade no período. Ao mesmo tempo, constata-se que, nessa região, a aristocracia local, em moldes veblenianos, desenvolveu um sistema impositivo que promovia os monopólios (pecuária e charque). 
[D]o sultanismo derivamos, na história de nossa formação social, para uma sociedade de homens interessados no poder e no mando, presos e guiados pelo impulso do poder [...] No Rio Grande do Sul, até o ponto onde se permite que haja um tipo regional de cultura, não se pode fugir a um traço permanente de sua orientação histórica que rompe todas as estratificações para impor-se: é o ascendente senhorial (Faoro apud Araújo; Fischer, 1998, p. 75). ${ }^{29}$

Assim, a natureza da organização das relações sociais afetava o desenvolvimento de ações individuais baseadas em formas capitalistas mais avançadas, em razão do baixo intercâmbio entre agentes, da propriedade concentrada da terra, da escravidão, da rigidez social e do vazio demográfico.

Entre 1814 e 1860, enquanto a população total do Rio Grande do Sul cresceu $286 \%$, a de Pelotas aumentou $754 \%$ e a de Rio Grande $884 \%$. Somado a isso, quando comparado com o restante do Brasil, o peso da economia pelotense centro charqueador - não era desprezível. Em 1880, Pelotas tinha a mesma população de Porto Alegre ou São Paulo. Dados municipais de 1920 apontam o município como o oitavo de maior renda no país, frente a Campinas e Santos. Também estima-se que, em meados do século XIX, o patrimônio dos charqueadores era suficiente para que adquirissem as maiores plantations de café disponíveis do Sudeste (Monastério, 2002, p. 88).

Mas, ao passo que a Coroa Portuguesa foi determinante para a formação da Campanha, distribuindo direitos de propriedade para seu povoamento e fazendo resultar - no dizer de Cardoso (1977) - uma estrutura social de castas (casta dos escravos e casta dos senhores), na região Norte do Estado seu papel foi outro.

(29) Cardoso (1977) explana sobre a "camada senhorial" sul-rio-grandense no início do século XIX: "Na verdade, a sociedade rio-grandense não só se organizou nos moldes de uma estrutura patrimonialista, como as posições assimétricas da estrutura social correspondiam formas de comportamento reguladas por rígidas expectativas de dominação e subordinação [...] O padrão de equilíbrio estrutural da sociedade gaúcha mantinhase, durante o século XVIII e início do século dezenove, através de formas autocráticas de dominação [...] parece que a violência e a arbitrariedade se inseriram de tal forma no sistema de relações sociais que se justificaria falar na perversão do sistema autocrático de mando no Rio Grande do Sul. O apelo ao arbítrio e à força bruta a tal ponto esteve presente no sistema de dominação existente no sul, que a violência e a falta de respeito às normas formalmente estabelecidas contavam como componentes de fundamental importância para a manutenção do sistema de controle social e para a motivação dos ajustamentos às condições normais de vida" (Cardoso, 1977, p. 84-85). Acrescenta-se a isso a visão de Monastério, que aplica o enfoque do Capital Social para a região (à la Putnam). Monastério (2002) caracteriza essa sociedade como "não-cívica". Para isso, o autor remete a seguinte passagem extraída do diário de um viajante francês do século XIX: “[...] os abusos atingiram o cúmulo, ou melhor, tudo era abuso. Os diversos poderes confundiam-se e tudo era decidido pelo dinheiro e pelos favores. $\mathrm{O}$ clero era a vergonha da Igreja Católica. A magistratura, sem probidade e honra [...] os empregos multiplicavamse ao infinito, as rendas do Estado eram dissipadas pelos empregados e afilhados, as tropas não recebiam seus soldos; os impostos eram ridiculamente repartidos; todos os empregados desperdiçavam os bens públicos; o despotismo dos subalternos chegou ao cúmulo, em tudo o arbítrio e a franqueza andando ao par da violência" (Saint-Hilaire apud Monastério, 2002). 
Passado 1/4 do século XIX, partiu do Império um projeto de colonização da área inabitada do Rio Grande do Sul. Para o Trono, a função desse projeto era criar um apoio político alternativo ao da grande propriedade. Assim sendo, o Império tinha objetivos particulares, como os de impedir a concentração de propriedade, gerar a exploração efetiva das áreas concedidas e garantir a ocupação efetiva do lote pelo colono e sua família. Outra característica interessante da política imperial de colonização foi a proibição do emprego de escravos. Pela Lei Geral n. 514, de 1848, a introdução e o emprego dos escravos, nas colônias, eram proibidos (Roche, 1969, p. 101).

A política de colonização de imigrantes europeus, baseada na pequena propriedade e no trabalho livre, fez com que surgissem no Rio Grande do Sul formas mais avançadas de comércio local, do uso de técnicas europeias capitalistas, e uma maior coesão social. Também, com a chegada de europeus ao Rio Grande do Sul no século XIX, principalmente no que diz respeito ao quesito "trabalho", os imigrantes trouxeram novos valores, costumes e hábitos, ou seja, outra cultura. Essa cultura estaria fundamentalmente mais ligada ao "espírito do capitalismo" (à la Weber), situação que era, até então, estranha para a realidade gaúcha. Esses fatores culturais viriam a legitimar em maior grau o capitalismo na região e, por conseguinte, a acumulação de capital, dada a maior especialização da oferta de trabalho.

Contudo, acrescenta-se que o surto industrial que ocorreria posteriormente nas colônias gaúchas não esteve ligado a invenções ou ao uso de técnicas avançadas e desconhecidas, mas sim deu-se através do emprego de técnicas já dominadas há décadas em países industrializados. Reproduzia-se, na região, o que já se havia visto na Europa, não exigindo dos imigrantes maiores conhecimentos nem investimentos muito elevados. Depoimentos pessoais e históricos de firmas retratam viagens ao exterior para a aquisição de máquinas, correspondência com outros países para informações sobre técnicas, imitação simplificada e adaptada e mesmo aplicação prática do que já se lia em manuais.

A necessidade de habilitação técnica foi suprida pelo envio dos filhos dos empresários à Europa em centros industriais famosos para estudarem e realizarem estágios. A segunda e a terceira gerações de industriais de descendência alemã, no Rio Grande do Sul, estudaram na Europa, aprendendo a manipular novas máquinas e recolhendo experiência técnica e organizacional (Pesavento, 1988, p. 60). ${ }^{30}$ Os imigrantes também criaram entidades com o objetivo de formar uma

(30) Os filhos do cervejeiro Ritter estudaram em São Paulo e em Munique, além de realizarem estágios na Saxônia e Áustria; os filhos de Carlos Rheingantz estudaram química e fiação em Aachen e em Saxen; os filhos de Bins estudaram em Dusselkdorf e ele próprio fez estágios na Alemanha e na Inglaterra; os filhos de Renner estudaram na Alemanha, Itália e EUA; Hugo Gerdau também estudou na Alemanha. Dentre os empresários de etnia italiana, Eberle visitou metalúrgicas na Alemanha e Itália. Lourenço Mônaco viajou à Itália para estudar inovações técnicas no engarrafamento do vinho (Pesavento, 1988, p. 60). 
mão-de-obra qualificada. Constituíram uma escola profissional, denominada de Gewerbeschule, que recebia contribuições financeiras da Alemanha. ${ }^{31}$

De acordo com o ideário neoschumpeteriano, é o desenvolvimento dessas formas de aprendizado que fornece o aumento da competência da firma, na medida em que auxiliam para que novos conhecimentos sejam agregados ao conhecimento tecnológico existente (Dosi, 1988 e Malerba, 1992). Além da importância da história técnica acumulada dos imigrantes para a origem do parque fabril gaúcho, os mesmos ainda manifestavam preocupação em criar competências, aprender a fazer, a usar e a interagir. Nesse sentido, a originária classe de industriais gaúchos revelava-se capaz de produzir um repertório de rotinas técnicas, importantes para a formação de caminhos, para a tomada de decisões estratégicas e para o aproveitamento de oportunidades existentes.

Já no século XIX definiram-se, no Rio Grande do Sul, dois “modelos” de industrialização distintos. Um teve como polo as cidades de Rio Grande e Pelotas, nas quais a indústria objetivava exportar sua produção para o mercado nacional, aproveitando-se das ligações já instituídas pelas exportações de produtos vindos da pecuária. As indústrias se caracterizavam por serem de grande porte e especializadas em poucos ramos. O outro "modelo" é aquele que se originou no eixo Porto Alegre-Caxias do Sul, assinalado pela diversificação de sua produção em diversos ramos e pela proliferação de pequenas empresas. Este último, ao contrário do que se desenvolveu no Sul, apoiou-se fundamentalmente no mercado regional (Mertz, 1991).

O mercado das zonas de colonização alemã e italiana apresentou-se mais eficaz, no sentido da industrialização, devido ao fato de, além da mão-de-obra especializada encontrada no conhecimento tácito e da preocupação dos imigrantes para com o aprendizado, essas colônias encontravam, no próprio mercado estadual e em outros mercados regionais do Brasil, um escoadouro para sua produção diversificada, que logo começou a ser beneficiada. Isso proporcionou, para o subsistema colonial-imigrante, a propagação do capitalismo e da produção mercantil, espraiando para a capital do Estado, Porto Alegre, um estímulo industrializante em virtude da atividade comercial que ali acumulava capital. $\mathrm{O}$ subsistema da pecuária, que tinha grande parte da concentração da indústria nessa época, também apresentou crescimento. Porém, as indústrias do Sul do Estado não apresentavam a mesma dinâmica, pois os novos estabelecimentos que ali surgiram

(31) Em seu currículo, figuravam disciplinas como desenho projetivo, mecânica, físico-química, estática, eletromecânica, resistência de materiais, planimetria, estereotomia, álgebra, etc., além de disciplinas de língua, como português, alemão, francês e inglês. Entretanto, com o início da guerra europeia, cessaram-se as contribuições financeiras da Alemanha e muitos dos filhos dos empresários tiveram de deixar de estudar na Europa. Todavia, dado o alto nível proporcionado pela Gewerbeschule, esta apresentou uma alternativa para o problema do aprendizado (Pesavento, 1988, p. 64). 
(exceto os ligados à transformação pecuária) não eram oriundos de atividades características do local, mas sim de investimentos realizados por imigrantes que visavam aproveitar as "economias" do Porto de Rio Grande, em função da exportação para outros mercados do Brasil. $^{32}$ Desse modo, apesar da diversificação e grande dispersão de pequenas unidades pelo interior do Estado, a indústria mostrou-se concentrada nas cidades de Rio Grande, Pelotas e Porto Alegre. Entretanto, nesta última, o parque industrial era de relativa importância econômica, visto que articulava, cada vez mais, o processo ao lado do Vale dos Sinos e da região Serrana.

De acordo com levantamento efetuado em 1907 pelo Centro Industrial do Brasil, quanto ao número de empregos, Pelotas e Rio Grande apresentavam ligeira vantagem em relação a Porto Alegre - 5.082 contra 4.888 trabalhadores, respectivamente. Em relação ao número de empresas, os dois parques manufatureiros mostravam diferenças estruturais significativas: enquanto Porto Alegre detinha um número de 114, Pelotas e Rio Grande, juntas, possuíam 77 empresas. Esse fato deve-se, como mencionado no parágrafo anterior, às grandes unidades desempenharem um papel mais importante no Sul do que no Norte do Estado. O número médio de empregados por empresa, nestas duas cidades da região Sul, era 50\% maior do que na Capital (66 contra 42,9) (Bandeira, 1994, p. 23). ${ }^{33}$

Para que se tenha ideia da importância industrial da cidade de Porto Alegre para o conjunto da indústria gaúcha, utilizamos os dados de Singer (1977, p. 174) para o ano de 1916: no ramo da metalurgia, as dez principais firmas alemãs, todas de Porto Alegre, produziam $40 \%$ do total do ramo no Estado; na industrialização do fumo, Porto Alegre estava em primeiro lugar, com $28 \%$ da produção do Estado; situavam-se em Porto Alegre três das quatro principais fábricas de papelão, as quatro principais fábricas de móveis (com $27 \%$ da produção do Estado), uma fábrica de pregos, etc. Também, Porto Alegre passou

(32) O parque industrial desse subsistema detinha forte presença de elementos de origem imigrante, particularmente burgueses imigrantes. "Veja-se o caso de Pelotas: em 1864, Friegrich Lang, possuindo experiência técnica no ramo, fundou uma empresa para fabricar velas e sabões; em 1880, Carlos Ritter, comerciante, estabeleceu-se com uma cervejaria. Em Rio Grande, o comerciante Carlos Guilherme Rheingantz fundou, em 1873, a primeira fábrica de tecidos do Rio Grande do Sul; em 1891, Gustavo Poock, filho de um fabricante de charutos na Alemanha, fundou uma fábrica deste tipo, e, no mesmo ano, o comerciante Albino Cunha formou a Moinhos Rio-grandenses para a fabricação de farinha de trigo" (Pesavento, 1985, p. 36).

(33) Corroborando a maior dinâmica do centro industrial de Porto Alegre em relação a Pelotas e Rio Grande, o Censo Industrial de 1907 constatava a maior diversificação da cidade gaúcha situada na região Norte. Mais de $80 \%$ dos ramos considerados na classificação estavam representados em Porto Alegre, 38 de um total de 47. Pelotas e Rio Grande, juntas, contavam com apenas 27 ramos. Somado a isso, em Porto Alegre, o gênero responsável pelo maior volume de ocupação de mão-de-obra era o de fiação e tecelagem, que gerava apenas $13 \%$ aproximadamente dos empregos. Por outro lado, em Pelotas, o charque respondia por cerca de $42 \%$ do total de emprego e, em Rio Grande, a fiação e a tecelagem concentravam mais de 60\% dos operários (Bandeira, 1994, p. 24). 
para o primeiro lugar no setor de tecelagem, com o extraordinário crescimento das empresas Renner, desbancando Rio Grande, onde localizavam-se as empresas de Rheingantz.

Conforme Paul Singer, a cidade de Rio Grande era ainda o maior centro industrial do Rio Grande do Sul no fim do século XIX, mas o ritmo de industrialização de Porto Alegre, a julgar pelo número de empresas fundadas entre 1890 e 1900, já era mais intenso. Consequentemente, em 1927, Porto Alegre deveria ser a primeira cidade industrial do Estado, pois sua indústria ocupava mais operários (8.718) que a de Rio Grande em 1940 (7.502) (Singer, 1977, p. 175). Ainda segundo o autor, é provável que Porto Alegre tenha assumido a liderança industrial do Estado na década de 1920.

O fato é que, nesse subsistema, existiam recursos não-mercantilizáveis, ou tácitos, como padrão de valores, cultura empresarial e experiência organizacional, que contribuíam para a formação de capacidades dinâmicas locais. Da mesma forma, portanto, que existia um padrão de comportamento idiossincrático nos agentes da Metade Sul, de acordo com as análises de Faoro (apud Araújo; Fischer, 1998) e Cardoso (1977), que indicam a configuração de uma sociedade extremamente hierarquizada, legitimada pelo costume e pela tradição local.

Isso vai ao encontro do argumento de imersão - ou enraizamento - social (embededdnes argument) elaborado pelo sociólogo Mark Granovetter (1985). A proposta da abordagem denominada "imersão social" (embeddedness) enfoca que as "ações econômicas" dos agentes estão "imersas" (ou enraizadas) em uma organização de relações sociais. Desse modo, os agentes econômicos teriam comportamentos dentro de uma rede dependente com outros agentes. Granovetter supõe que o comportamento dos indivíduos não é movido apenas pela racionalidade econômica, mas também pela "sociabilidade, a aprovação, o status e o poder". Se aceitarmos que as duas regiões possuíam matrizes institucionais distintas, é de se supor que as ações individuais dos agentes econômicos sofriam estímulos diferenciados pelo enredamento específico das relações sociais presentes em cada uma das configurações históricas.

Nas relações sociais da região Sul estavam legitimados comportamentos patrimonialistas, autoritários e sancionadores da grande propriedade, decorrentes da estruturação senhorial e estratificada dessa mesma sociedade. A outra sociedade foi criada como contrapeso à anterior, diferenciando-se, sobretudo, pela pequena propriedade e pela "imigração espontânea". Como bem diz Targa (1996), os imigrantes foram encarregados de criar uma nova sociedade, totalmente à parte da sociedade escravista, em que o trabalho escravo era legalmente interditado. Assim, a estrutura da propriedade, no Rio Grande do Sul, deu origem a uma estrutura social e produtiva na qual conviviam grandes latifundiários pecuaristas, 
charqueadores, pequenos agricultores, comerciantes e industriais. Tais agentes não se encontravam espraiados de forma homogênea por todo o território gaúcho, uma vez que ocupavam regiões distintas, a partir da definição dos direitos de propriedade sobre a terra e do resultante mecanismo de relações sociais instituído em cada local. $\mathrm{O}$ que as duas regiões passariam a ter em comum já no início do século XX era a orientação para o mercado interno brasileiro, mas o que as diferenciava eram as formas de acesso à propriedade e os estímulos econômicos provenientes de cada matriz institucional.

Dessa forma, os direitos de propriedade e as ações individuais dos agentes econômicos de cada região não são regidos somente por direitos e sanções regulamentadoras, mas também por hábitos, costumes e valores, ou seja, pelo direito consuetudinário (pela cultura, como é sabido). Percebe-se que estes últimos fazem com que o passado exerça sua carga sobre o presente e o futuro afetando a evolução institucional e, portanto, econômica de determinada região. Assim, a natureza das relações sociais - da cultura, das instituições, do "meio social" em que as ações individuais estão enraizadas (embeddedness) - também afeta o desempenho econômico no longo prazo.

\subsection{Mudança institucional e tecno-produtiva}

A ocasião da Primeira República no Rio Grande do Sul revelou-se muito importante para a história socioeconômica regional, pois é justamente nesse período que a economia, a política e a sociedade gaúcha sofrem grande transformação. Esse período é fundamental para a compreensão da evolução industrial do Rio Grande do Sul, bem como para a compreensão da disparidade econômica regional, já que é nessa época que os distintos arranjos econômicos do Estado corroboram suas especificidades e expandem suas relações capitalistas. Acredita-se que ocorreu uma mudança institucional no Rio Grande do Sul durante a Primeira República, visível pelo deslocamento do poder da antiga classe dominante. Essa mudança foi determinante da alteração nas bases produtivas regionais. $\mathrm{O}$ projeto do Estado positivista, visando à diversificação produtiva e à ampliação do mercado interno, distinguiu a economia gaúcha do período anterior (Império). A política, nesse contexto, determinou quais os interesses iriam prevalecer.

North (1994) discute o "dilema da mudança institucional". Mudanças lentas e graduais, muitas vezes, serão prejudiciais, ao final, pela criação de "direitos de corrupção" entre a burocracia vigente. A consequência é que alterações radicais de política devem vir acompanhadas de uma reestruturação radical da burocracia. Por isso, mudanças bruscas trarão comoção social e política, porque as limitações informais e as percepções ideológicas simplesmente não mudam de repente. Nisto estaria fundado o dilema da mudança institucional. 
O novo grupo no poder (PRR) tinha uma ideologia burguesa, que se caracterizava pela eficiência administrativa, moralidade nos negócios públicos, nitidez e transparência das contas regionais, orçamento equilibrado (praticamente em todo o período da Primeira República o orçamento estadual apresentou superávits) e promoção de políticas que visavam ao bem-estar material e ao progresso da sociedade. Com isso, o PRR não tinha natureza oligárquica quanto ao seu funcionamento e nem desfrutava de uma rede de relações coronelísticas para garantir a sua reprodução no poder (Targa, 1998). ${ }^{34}$

Dessa forma, seguindo a partir da teoria de North, com o PRR ocorreu uma mudança institucional radical no Rio Grande do Sul. Este partido político buscou a modernização social, política, e consequentemente econômica, em detrimento das instituições tradicionais do Império. Assim, ocorreu uma mudança no ideário político/econômico do Estado com a ascensão do Partido Republicano Riograndense. ${ }^{35}$

Tal mudança de ideário teve forte implicação no desenvolvimento regional, confirmando o pensamento de North (1994), no qual a ideologia exerce uma grande influência na constituição das regras formais de uma sociedade, visto que penetram na tomada de decisão dos agentes políticos. As ideologias, além de estarem na base da formação das regras informais, definem sobremaneira as regras

(34) Mesmo defendendo a livre iniciativa e preconizando a concorrência contra o regime de monopólio, o PRR não aceitava a supremacia do livre mercado sobre a vida social. Admitia-se a intervenção do Estado na vida econômica, sempre que isso fosse necessário ao equilíbrio e à harmonia da sociedade. Todavia, mesmo que a interferência do Estado no campo econômico fosse válida, ela não deveria manifestar-se na forma de privilégios específicos, e sim deveria ocorrer somente quando as questões afetadas tornavam-se sociais, quando viessem em benefício de toda ou da maior parte da coletividade (Herrlein Jr., 2000, p. 60). Dessa forma, os republicanos sulrio-grandenses entendiam que ao Estado cabia um papel fundamental na organização da sociedade, garantindo a harmonia social (ordem) e promovendo o desenvolvimento econômico (progresso) (Pinto apud Herrlein Jr., 2000, p. 59). Assim o PRR propunha-se a resolver os problemas que se antepunham ao livre desenvolvimento das forças produtivas, além de promover um desenvolvimento econômico multilateral no Estado. O projeto desse partido implicava a tentativa de efetivação do capitalismo de forma global, onde, indistintamente, todos os setores da economia gaúcha se desenvolvessem. Por isso, o desenvolvimento do capitalismo no Rio Grande do Sul precisava atender outros setores produtivos, não mais somente os da agropecuária, como no Império, para garantir a sua base de sustentação.

(35) Vejam-se os principais fatores condicionantes da mudança. Sucintamente, o governo republicano criticava a legislação tributária do Império, baseada no Imposto de Exportação, alegando que os princípios que a regiam eram "antieconômicos". Dessa maneira, empossado, após o período conturbado de guerra contra os federalistas, o Partido Republicano Riograndense primeiramente praticou uma reforma tributária no Estado. Implementou um projeto decidido a substituir os impostos indiretos por diretos, propondo tributar diretamente a propriedade e não, indiretamente, a produção. Para isso, o PRR substituiu, em grande parte, o Imposto de Exportação pelo Imposto Territorial. Suavizou a carga fiscal sobre os agricultores, bem como sobre as formas agrária, comercial e industrial do capital. Assim sendo, a política buscava, principalmente, reduzir a carga fiscal ou isentar de impostos o capital mercantil. O dinamismo da economia regional tendia a se desvincular, progressivamente, da grande propriedade. Além disso, o PRR construiu uma infraestrutura de transportes, estatizando portos e estradas de ferro, sobretudo para estimular a reprodução ampliada do capital comercial e da classe dos pequenos proprietários e proteger a indústria nascente (Targa, 2003). 
formais. Por isso, mudanças nas regras informais na sociedade gaúcha, como a mudança ideológica do Estado Regional, redundaram em transformações nas regras formais (leis, tributos, etc.). Sabe-se que, na concepção de North (1994), inspirado em Thomas Kuhn, a manutenção de uma ideologia depende de sua capacidade de explicar o mundo à sua volta; foi essencialmente isso que o PRR fez para perpetuar sua ideologia positivista. Diante da crise da pecuária e das charqueadas, o Estado promoveu a diversificação econômica, ganhando argumentos para resistir às demandas de privilégios por parte das classes tradicionais. Diante deste quadro, enfraquecia a tese da defesa da especialização pecuária, como projeto político/ideológico de desenvolvimento econômico estadual, diante do sucesso da política de diversificação produtiva do ideário positivista.

Por sua vez, a mudança de ideologia encontra forte reforço nas organizações, consideradas por North (1994) como principais agentes da mudança institucional. ${ }^{36}$ Nestas, os agentes (políticos e/ou econômicos) têm a capacidade de perceber oportunidades e concretizar as fontes da mudança. No curso deste processo, desenvolvem-se mecanismos de aprendizado, sobretudo através da aquisição de diferentes tipos de conhecimento, e firma-se um modelo mental dos quais os agentes participam como jogadores. ${ }^{37}$ Os agentes, em geral, pesam as potenciais vantagens de uma reformulação de contratos no arcabouço institucional existente contra o retorno obtido do investimento na reforma desse arcabouço (mudança nos insumos e na produção). Se reformularem contratos, mudarão as regras formais, caracterizadas por reformas legislativas tais como a aprovação de novas leis. Se optarem por investimentos produtivos na busca por mudanças, estão mudando regras informais. Todavia, de acordo com o ideário institucionalista, regras informais não mudam de forma abrupta, ocorrendo muito mais gradativamente e ao longo dos tempos, o que depende da taxa de aprendizagem dos empresários.

No Rio Grande do Sul, os empresários da Campanha, sucessivamente, buscaram reformular os contratos no arcabouço institucional existente, ou seja, mudaram as regras do jogo por meio de mudanças nas regras formais. Economicamente, os empresários optaram por continuar atrelados ao salgamento

(36) As organizações são formadas por grupos de indivíduos aglutinados com o propósito de alcançar certos objetivos. As organizações incluem: a) corpos políticos (partidos políticos, senado, municipal, corpos reguladores); b) corpos econômicos (empresas, sindicatos, cooperativas, etc.); c) corpos sociais (Igrejas, clubes, associações desportivas); d) corpos educativos (colégios, universidades, etc.) (North, 1993, p. 7-8).

(37) Quando os agentes deparam-se com mudanças em preços relativos ou em preferências e gostos, eles têm duas opções para assegurar as novas oportunidades de ganho econômico. A primeira é investir em recursos, rearranjar a relação de insumos e produtos com que trabalham. Essa opção depende da aquisição de diferentes tipos de conhecimento e aprendizagem. A outra opção é investir em esforços no campo político para mudar a matriz institucional, no intuito de alterar leis, contratos e normas formais. Fazendo assim, as organizações irão capturar os ganhos decorridos da mudança no ambiente. 
da carne, por exemplo, não investindo recursos no processo de frigorificação, o que demandaria um esforço de aprendizagem e mudanças em regras informais. ${ }^{38}$ No período republicano, os empresários gaúchos da pecuária continuaram tentando reformular contratos ao invés do rearranjo produtivo. A discussão político-ideológica, intensa na Assembleia dos Representantes do Rio Grande do Sul durante praticamente todo o período da Primeira República, demonstra a persistência dos agentes da região Sul em mudar regras formais para maximizarem o retorno de suas atividades, em detrimento de atitudes produtivas (Fonseca, 1983).

Ao que parece, para a elite empresarial do Sul era melhor transferir a questão da mudança institucional para a arena política. Assim, a concorrência externa (mudança em preços relativos) podia até trazer consigo possíveis empresários perdedores no campo econômico, mas estes se utilizavam do artifício político para corrigir suas perdas, alterando a estrutura de preços relativos. ${ }^{39}$

Mas, então, por que essa rigidez institucional não se manifestou no outro subsistema econômico do Rio Grande do Sul? A resposta é simples. Com a transição capitalista e a implantação de uma nova ideologia no Estado, a Metade Norte pôde legitimar mais facilmente a matriz institucional precedente ao período. A ideologia ou o modelo proposto pelo governo republicano não se chocava com as limitações informais (cultura acumulada ao longo do tempo) da sociedade colonial, mas principalmente corroborava um sistema econômico já instituído.

(38) Como exemplo de mudanças em preços relativos, considera-se a concorrência dos saladeiros do Rio da Prata. Esses, ao entrarem no mercado brasileiro, praticavam um preço mais competitivo, desbancando o produto gaúcho. Os empresários (charqueadores) poderiam rearranjar a relação insumos/produtos com que trabalham. Adotando essa conduta, deveriam os empresários da Campanha desenvolver padrões alternativos de comportamento - no caso, mais produtivos e competitivos. Por isso, havia a necessidade de aquisição de novos conhecimentos ou de aprendizagem. Os empresários do Sul preferiam mudar a matriz institucional reformulando contratos, sem introduzir mudanças no padrão de produção. Tal conduta já era recorrente no passado, como manifestada na Guerra dos Farrapos (1835-1845): reivindicações da classe dominante local para o Império. Alegavam o descaso da política imperial em relação à proteção do produto gaúcho. Dez anos de guerra resultaram em um aumento do imposto de importação para o charque platino em 25\%. Assim, os empresários do Sul reformularam a matriz institucional mediante leis e normas formais. Os incentivos da mudança nos preços relativos (concorrência) não alteraram a lógica interna produtiva.

(39) Logo, a mudança nos preços relativos (concorrência platina) afeta a conduta dos possuidores de recursos econômicos que se manifestava em câmbios políticos e contratuais. Perpetuava a matriz produtiva vigente, com ajustes incrementais, pois se podiam alterar os preços relativos através de tributos ao charque platino de melhor qualidade. Entendendo a dinâmica, segundo North (1995, p. 17), mesmo que as normas formais mudassem repentinamente (como resultado de decisões políticas), as limitações informais enraizadas em costumes, tradições e códigos de conduta eram muito mais resistentes, o que restringia a modernização do setor. A taxa de aprendizado dos charqueadores, que se deu ao longo dos tempos, manifestava-se por esse comportamento. $\mathrm{O}$ estoque de conhecimentos dessa classe, identificado também por sua ideologia, justificava o monopólio e, sendo assim, menor era o incentivo para aprender e mudar. Ainda conforme North (1993), a aprendizagem é filtrada pela cultura de uma sociedade, a qual determina os retornos percebidos, não garantindo que essa experiência acumulada no passado resolverá os novos problemas. 
Dessa forma, a evolução econômica dessa região foi "incentivada". Não se exigiu que os agentes desse local modificassem a matriz institucional vigente, mas que a aprofundassem.

A ascensão do subsistema econômico do Norte do Estado ocorreu porque a natureza das relações sociais presentes nessa região não era contraditória à prática da ideologia positivista. É bem certo que, se a nova política praticada pelo PRR não estivesse de pleno acordo com os hábitos de pensamento dos agentes do Norte do Estado, seu desenvolvimento não ocorreria da mesma forma. Todavia, tal fato não ocorreu, e a promoção do desenvolvimento da região colonial-imigrante deu-se pela corroboração de práticas produtivas capitalistas, enraizadas (embedded) nos valores, nos hábitos e na cultura dos agentes econômicos locais. Assim, pode-se dizer que a matriz institucional do subsistema colonial-imigrante necessitava de um impulso para "deslanchar", fato que ocorreu com a prática do ideário positivista.

O câmbio político, a prática do positivismo e as políticas institucionais determinaram transformações econômicas para o Estado gaúcho. Essas mudanças estimularam a transformação de recursos produtivos locais, proporcionando, primeiramente, bens para o próprio mercado, caracterizando uma autossuficiência estadual e, posteriormente, exportações para as demandas do resto do país. Esse fato histórico é visualizado pela abrangência e diversidade de transações do subsistema do Norte, que não se limitaram apenas ao mercado local, mas, sobretudo, ao estadual e nacional, determinando em boa medida a acumulação de capital necessária ao desenvolvimento industrial gaúcho. Para Herrlein Jr. (2000, p. 49), a nova "qualidade" da economia gaúcha revela-se pela capacidade adquirida de ampliar e diversificar sua estrutura e oferta, a partir do desenvolvimento agrícola, comercial e industrial do subsistema colonialimigrante.

\subsection{Lock-in, catching-up e path dependence}

O período compreendido pela Primeira República demonstra a debilidade frente à transformação da região Sul. Além de manter-se ligada a suas origens e ideologia, deparava-se com relativa crise econômica. A produção fundamentava-se no beneficiamento da atividade pecuária e, nesse sentido, apresentava-se pouca diversificada e com baixa agregação de valor, além de atender somente a demanda da população pobre.

Entretanto, enquanto a Campanha gaúcha se mantinha enraizada à charqueada como forma principal de industrialização da carne, a região do Prata arrancara para uma fase de maior avanço tecnológico, com a instalação de frigoríficos já no século XIX. Ao passo em que Argentina e Uruguai progrediam 
na indústria do frio, regredindo suas atividades saladeristas, a região Sul do Rio Grande do Sul aprofundava cada vez mais sua atividade produtiva em um produto tecnologicamente inferior. $O$ aprofundamento da especialização pode ser constatado através do aumento do quantum exportado: as exportações de charque se expandiram, em termos reais, à taxa de 3,2\% a.a. entre 1890 e 1927 (Almeida, 1992).

A problemática da produção especializada da região Sul e de seu baixo dinamismo no longo prazo requeria atitudes locais que levassem a Campanha à mudança, e o exemplo estava ao lado: migrar da produção de charque para a frigorificação da carne. Abriu-se uma janela de oportunidade para o setor pecuarista. Ocorreu uma inovação tecnológica radical no setor de alimentos específico dessa região, ou seja, uma mudança de paradigma. ${ }^{40}$

Como se sabe, o surgimento de um novo paradigma dá-se ainda em um mundo dominado pelo velho paradigma, sendo mais importante deslocar o velho mediante uma radical mudança no "senso comum". No caso, o velho seria a charqueada, e o novo, o frigorífico. Entretanto, mudanças requerem algum esforço, ou aprendizado tecnológico. Diferentemente da conjuntura do complexo colonial-imigrante, onde, por exemplo, empresários destinavam seus filhos à Europa para adquirirem conhecimentos técnicos, em nenhum momento constata-se alguma forma de aprendizagem para a técnica de frigorificação entre os empresários da Campanha.

O baixo dinamismo econômico e a elevada especialização produtiva do setor industrial ao longo do tempo, extremamente dependente do beneficiamento de atividades ligadas à pecuária, remetem a questões relativas a uma trajetória dependente do passado. Segundo a Teoria dos Custos de Transação, a principal característica de uma transação deve ser expressa na especificidade do ativo a ela relacionado (Williamson, 1985). Assim, a especificidade refere-se ao grau em que um ativo pode ser reempregado para usos alternativos ou por outros agentes, sem que haja perda de sua capacidade ou valor produtivo.

(40) A teoria neoschumpeteriana mostra que, nos períodos de transição tecnológica, ocorrem os momentos com a maior probabilidade que países emergentes têm para alcançar os líderes e, inclusive, ultrapassálos. Isso resulta das condições que se considera características do período de transição: a descontinuidade do progresso técnico e a prolongada duração do período de adaptação para os países líderes do paradigma anterior. O que se quer dizer com isso é que a Campanha poderia ter aproveitado essa "janela de oportunidade" - instalação de frigoríficos - e equiparar-se aos países platinos, ou até ultrapassá-los, se inovassem no setor. O fato é que não se instalaram frigoríficos na fase inicial do paradigma, sobretudo com capitais locais, como nos países platinos. Se isso tivesse ocorrido, a Metade Sul encontraria uma fase de crescimento rápido, de alta acumulação. Não se adaptando à mudança técnica, a região continuou sendo superada por seus concorrentes, e o hiato produtivo ampliava-se cada vez mais, fato que exercia influência negativa para o processo de desenvolvimento industrial da região. Como bem explica Utterbach (1996), sempre que ocorrem descontinuidades tecnológicas, as fortunas mudam de forma dramática. 
Possuía o sistema de produção pecuário-charqueador ativos específicos? Para Marques (1990), as charqueadas apresentaram relativo progresso, evoluindo de "charqueadas velhas" (século XIX) para "charqueadas modernas" (início do século XX). Nesses estabelecimentos modernos, chegava-se a aproveitar integralmente o boi, pois, através de atividades derivadas, as charqueadas passaram a fabricar, além do charque e couros, produtos como velas, sabões e glicerina, extrato de carne, conservas enlatadas, botões e pentes, pincéis, cordas para violão, dados, agulhas de tricô, colas, etc. Consequentemente, os investimentos para um melhor aproveitamento do boi aumentaram nas charqueadas, podendo considerar específicos os ativos para essas transformações, pois dependiam somente da matéria-prima ("boi"). Logo, percebe-se que as modernas charqueadas apresentavam custos irrecuperáveis (sunk costs), sendo que qualquer rompimento de contrato (compra do boi junto ao estancieiro) implicava ao charqueador, referente a seus ativos, a perda total de seu valor produtivo, ou a usos alternativos de baixo retorno.

Ademais, o alto grau de especificidade dos ativos da principal atividade econômica da Metade Sul geraria efeitos path dependence para a região, já que a própria evolução técnica e organizacional da charqueada faria com que se tornasse altamente custosa a transição para a frigorificação, em função dos custos irrecuperáveis encontrados nas charqueadas. Dessa forma, a decisão de investimento nesse processo produtivo, em algum ponto do tempo, levaria a definir uma trajetória de eventos prováveis, concomitante ao efeito de lock-in (rigidez, fechamento) em que a saída de tal trajetória é de ampla forma traumática ou mesmo inviável (em termos tecnológicos e/ou organizacionais). ${ }^{41}$

Somado a isso, verifica-se que, no período pós-1930, até meados do século $\mathrm{XX}$, as principais demandas perante o poder público desse complexo restringiam-se a vários fatores: a criação de um frigorífico com capital nacional, para assegurar o nível de renda e concorrer com o monopólio dos frigoríficos estrangeiros; a recursos financeiros para a criação de charqueadas de produtores, sob a forma de cooperativas ou associações; a criação de infraestrutura adequada para o transporte de carne e o fomento e assistência técnica e sanitária para o melhoramento da pecuária (Dalmazo, 1992, p. 32). Nesse sentido, desde o século XIX até meados do século XX, a elite empresarial da região Sul não se diversificava nem em relação às suas demandas perante o Estado Regional,

(41) O conceito de lock-in diz respeito ao fato de certos processos mostrarem bifurcações provocadas por pequenos eventos circunstanciais (históricos) que imprimem, primeiramente, uma mudança de direção que se torna gradualmente irreversível. Essa irreversibilidade na trajetória adotada é a chave para o conceito de path dependence (dependência da trajetória), já que, uma vez que o processo econômico entrou numa rota, existem forças internas que impossibilitam abandoná-la espontaneamente. Dessa forma a estrutura econômica torna-se crescentemente rígida, sendo mais difícil de ser alterada. Assim, o curto prazo condiciona o longo prazo (Licha; Oreiro, 1998). 
concentrando a atividade econômica fundamentalmente na pecuária, manifestando-se, pelo tempo, a rigidez estrutural (lock-in) da região. Accurso et al. (1965) alertavam para a rigidez estrutural da economia gaúcha, extremamente dependente do setor primário, além do caráter não reprodutivo do capital.

Situação diferente apresentava a Metade Norte do Estado no período pós1930, no que se refere à dinâmica industrial. Conforme Suzigan (1986), com a ampliação do mercado interno no período pós-1930, receberam impulso não somente a produção de bens de consumo não-duráveis, mas também muitos segmentos voltados para a produção de bens de consumo duráveis, intermediários e de capital leves. Assim, no tocante à indústria gaúcha, é a partir do período de substituição de importações que as diferenças estruturais internas entre as regiões, materializadas no período pré-1930, começam a determinar o desempenho de ambas. Na Metade Sul, a indústria local destacava-se pela produção de charque e pela presença de frigoríficos estrangeiros, com características de serem atividades exportadoras para fora do Estado. Porém, com o processo de substituição de importações em marcha, os segmentos dinâmicos do processo de desenvolvimento industrial caracterizavam-se naqueles direcionados para os mercados locais e regionais. Portanto, nesse período, foi a estrutura industrial da Metade Norte do Estado que apresentou uma dinâmica mais atrelada ao padrão de acumulação nacional substitutivo de importações. Isso porque as atividades características desse padrão de acumulação concentravam-se, especificamente, na região de Porto Alegre e nas principais cidades do complexo colonial-imigrante, por essas estarem essencialmente voltadas ao mercado local. ${ }^{42}$

Outro fator que ajuda a esclarecer o surgimento de aglomerações industriais na Metade Norte do Estado foi a busca por especializações locais. Com a ampliação do mercado interno e o aumento da concorrência inter-regional, aumentou a defasagem entre a indústria gaúcha em relação ao centro econômico do país. A saída encontrada por muitos setores industriais foi a especialização em

(42) Segundo os dados relativos à participação das Metades do Estado no pessoal ocupado da indústria gaúcha, compilados por Bandeira (1994), para meados da década de 1930, os segmentos industriais com maior complexidade tecnológica localizavam-se na Metade Norte do Estado. Em 1937, referente ao pessoal ocupado na indústria do Rio Grande do Sul, a Metade Norte do Estado tinha uma participação de aproximadamente 65\% do total. Desse total, a região Nordeste (colonial) detinha 46,32\% do pessoal ocupado na indústria, destacando-se nos gêneros têxtil $(63,15 \%)$, couros e peles $(44 \%)$, metalurgia $(68,8 \%)$, cerâmica $(51 \%)$, química $(70 \%)$, vestuário $(76,6 \%)$, mobiliário $(64,2 \%)$, edificação $(40 \%)$, aparelhos de transporte $(42 \%)$ e indústrias de luxo (85\%) (Bandeira, 1994, p. 42). A Metade Norte-Nordeste apresentava-se também mais diversificada, pois os gêneros têxtil, couros e peles, madeira, metalurgia, cerâmica, química e alimentação correspondiam por cerca de $62 \%$ de todo o pessoal ocupado da indústria nessa região, ao passo que, na região Sul, apenas o gênero alimentação absorvia praticamente $60 \%$ do pessoal. 
determinados ramos, tendendo também à concentração industrial e a uma especialização dos ramos por município. ${ }^{43}$

Por sua vez, é a partir dos anos 1950, com o Plano de Metas, que se inicia no Brasil a montagem de setores de maior complexidade tecnológica, como a implantação das indústrias de bens de capital e de bens de consumo duráveis. Sob este quadro, a estrutura produtiva regional apresentou condições para fazer o catching-up ao plano de desenvolvimento em curso, cujo núcleo voltava-se para a instalação de segmentos industriais dinâmicos na economia nacional.

Para captar o processo de instalação das indústrias responsáveis pela modernização do parque fabril gaúcho no período posterior à década de 1960, utilizou-se uma amostra dos dez principais municípios da Metade Sul e da Metade Norte, na evolução do número de empregados e de estabelecimentos na indústria de transformação do Rio Grande do $\mathrm{Sul}^{44}$ Os bens caracterizados como "dinâmicos" da indústria gaúcha referem-se à agregação dos gêneros minerais não-metálicos, metalurgia, mecânica, papel e papelão, borracha, química, produtos de matérias plásticas, material elétrico e de comunicações e material de transporte. Tais gêneros industriais são característicos da Segunda Revolução Industrial, evidentes do paradigma "fordista" no qual o Brasil ingressou, sobretudo, a partir dos investimentos do Plano de Metas e do II Plano Nacional de Desenvolvimento (PND).

Pelos Gráficos 1 e 2 (a seguir) percebe-se claramente que, ao longo das décadas posteriores à reestruturação da indústria gaúcha, foi exclusivamente na

(43) No setor metal-mecânico, por exemplo, definiram-se duas áreas de concentração no Rio Grande do Sul: Caxias do Sul e Porto Alegre. As empresas desse setor, voltadas fundamentalmente para as necessidades locais, especializavam-se na fabricação de um determinado tipo de máquinas e implementos. A indústria do couro e calçados concentrou-se em São Leopoldo e Novo Hamburgo; a indústria de alimentação, em Rio Grande e Pelotas (frigoríficos e conservas). Em Caxias do Sul, também predominou a concentração dos estabelecimentos vinícolas do Estado; a têxtil, em Porto Alegre, etc. (Pesavento, 1985, p. 72-90).

(44) Optou-se por escolher dez municípios representantes de cada Metade (Norte e Sul) do Estado pela dificuldade de agregação de todos os municípios do Rio Grande do Sul, o que levaria tempo e demandaria muito esforço, além de não ser o objetivo principal do presente estudo. A escolha levou em consideração o número de habitantes (mais de 100 mil) e a importância histórica do município. Os municípios referentes à Metade Norte são: Porto Alegre, Passo Fundo, Caxias do Sul, Novo Hamburgo, São Leopoldo, Cachoeirinha, Gravataí, Alvorada, Canoas e Triunfo. Triunfo não apresenta população maior que 100 mil habitantes, mas foi incluída por nela se situar o Pólo Petroquímico do Estado e por fatores históricos. As cidades da Metade Sul são: Rio Grande, Santa Maria, Pelotas, Bagé, Uruguaiana, São Gabriel (60.111 habitantes), Alegrete (84.743), Santana do Livramento (94.627), Cachoeira do Sul (86.526) e Rosário do Sul (40.897). Os cinco primeiros municípios são os únicos da região com mais de 100 mil habitantes. Apesar do número reduzido dos demais municípios mencionados, a amostra concentra elevada participação do total do emprego do Estado. Para o ano de 1970, os 20 municípios concentravam mais de $60 \%$ do número de empregados na indústria de transformação do Rio Grande do Sul. Em 1995, a participação destes municípios era de mais de 40\%. A metodologia utilizada referente à evolução do número de estabelecimentos dinâmicos para a Metade Sul e Metade Norte é a mesma para o número de empregados (FEE, 2001).

Economia e Sociedade, Campinas, v. 19, n. 2 (39), p. 381-420, ago. 2010. 
Metade Norte que se ampliou o emprego de trabalhadores destinados à produção de bens dinâmicos, característicos da modernização do parque industrial gaúcho. Verifica-se, também, que o número de estabelecimentos destinados à produção de bens dinâmicos, no Estado, apresentou evolução surpreendente somente nesta região do Rio Grande do Sul.

Do ponto de vista do desenvolvimento econômico, o subsistema colonialimigrante acumulou maior volume de investimentos em geral, ao longo do século $\mathrm{XX}$, mas, especialmente, na sua segunda metade, assegurando-lhe a consolidação da posição de região mais desenvolvida do Estado. Confirma essa afirmação o fato de estarem aí concentrados 70\% (em 2001) do parque industrial gaúcho (Alonso, 2003). Em vista dessas indicações, afirma-se que apenas uma região do Estado gaúcho conseguiu vincular-se ao modelo de industrialização capitalista brasileiro do pós-guerra. Com isso, a evolução da disparidade econômica regional foi determinada pelo próprio processo de desenvolvimento industrial do pós-1950, em consonância com o paradigma tecno-produtivo nacional. Assim, a região que se inseriu nessa nova dinâmica participou das fases de crescimento da economia brasileira.

A definição dos direitos de propriedade no Rio Grande do Sul (no século XIX), o tipo de estrutura social e a cultura acumulada dos agentes de cada subsistema econômico originaram ambientes institucionais particulares no Estado. Tais ambientes institucionais determinaram a trajetória industrial das regiões, pois influenciaram percepções e escolhas dos agentes locais a respeito das recompensas esperadas. Assim, foram os conhecimentos e a aprendizagem adquirida no tempo que refletiram as oportunidades de investimentos em atividades produtivas locais.

Gráfico 1

Número de empregados nos setores dinâmicos da indústria gaúcha nas dez principais cidades da Região Norte e da Região Sul do Rio Grande do Sul, 1970 a 1995

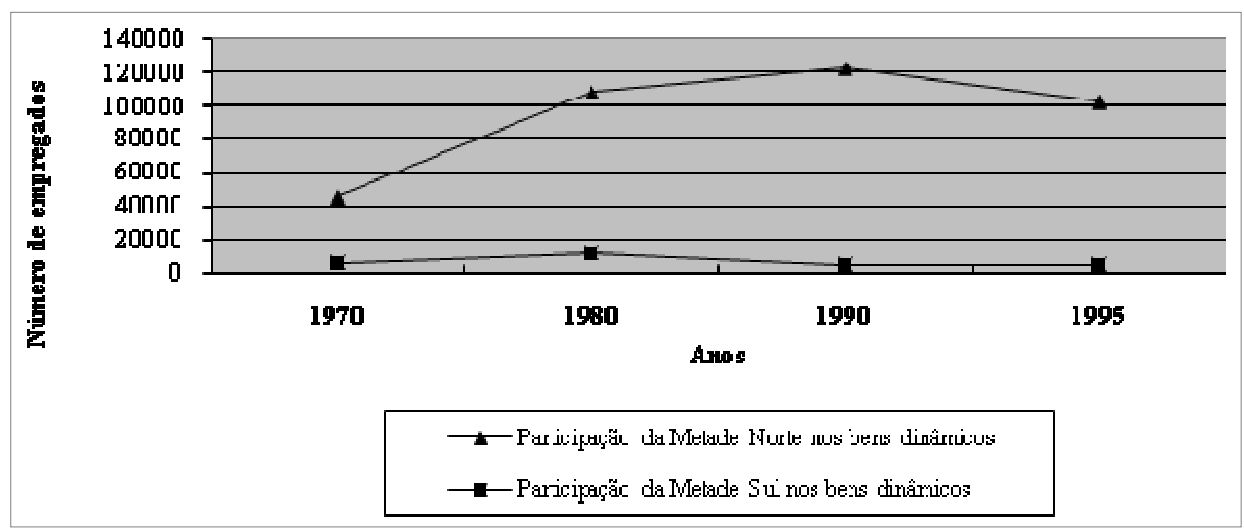

Fonte dos dados brutos: IBGE (1970 e 1980); FEE (1990 e 1995). 
Gráfico 2

Número de estabelecimentos nos setores dinâmicos da indústria gaúcha nas dez principais cidades da Região Norte e Região Sul do Rio Grande do Sul, 1960 a 1990.

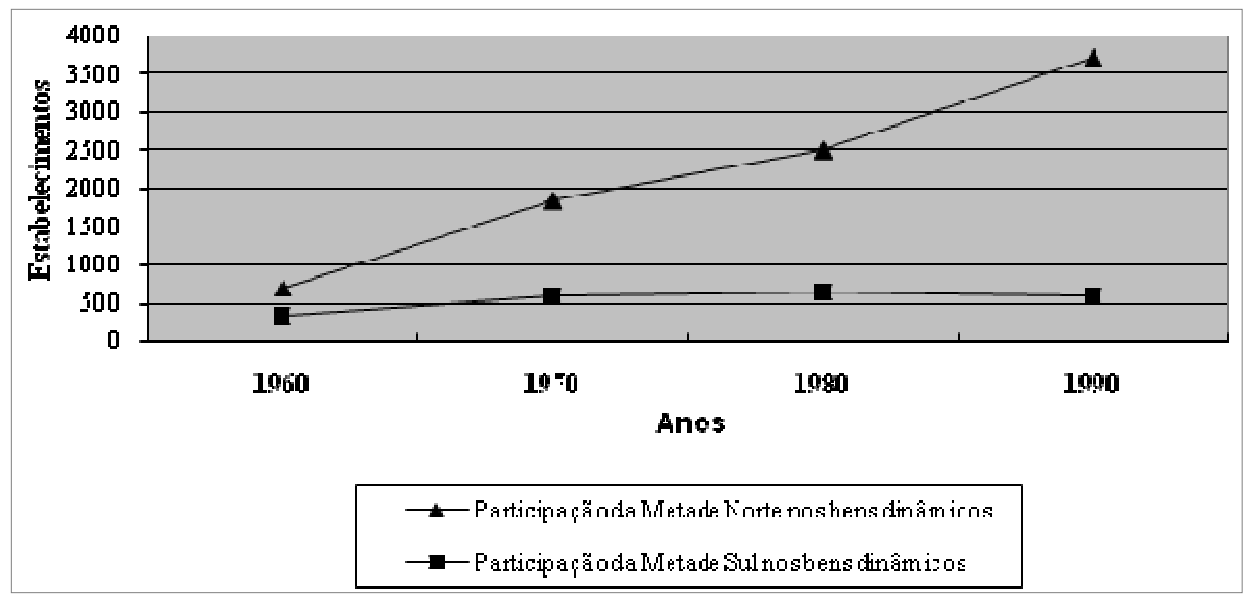

Fonte dos dados brutos: IBGE (1960, 1970 e 1980); FEE (1990).

A possibilidade de retornos crescentes da atividade produtiva ligada à pecuária fez com que pecuaristas e charqueadores escolhessem determinadas formas específicas de organização (charqueadas, trabalho escravo, frigoríficos), excluindo outras. A principal característica dessa evolução foi que a possibilidade de continuar escolhendo a atividade produtiva inicial (extremamente associada à pecuária) aumentou com sua prática, em função da aprendizagem e de externalidades criadas pela matriz institucional. Foi a partir dessa escolha das primeiras atividades produtivas que a Metade Sul excluiu outras atividades. Desse modo, a escolha é racional, mas a presença de externalidades criadas pela aprendizagem dos agentes estabelece que condicionantes históricos impliquem que o processo selecione certa atividade produtiva e exclua outra, podendo a região apresentar uma rigidez estrutural (lock-in), institucional e tecnológica.

No percurso original, existiam fortes complementaridades no comportamento dos agentes, de forma que era vantajoso adotar uma tecnologia porque ela já era adotada antes por outros agentes. Havia várias estruturas produtivas candidatas a serem escolhidas no longo prazo, mas a história selecionou apenas uma. Assim, a Metade Sul, nos primórdios, selecionou uma matriz produtiva e excluiu outras. No passado, os agentes não podiam prever $e x$ ante qual seria a matriz produtiva mais dinâmica, e a história mostrou que o processo pode selecionar tecnologias e instituições com retornos menores no longo prazo. Embora o subsistema pecuário-charqueador tenha sido altamente rentável 
no século XIX, do ponto de vista histórico evolucionário não o foi, levando a região a uma opção inferior. ${ }^{45}$

No caso da região Norte do Rio Grande do Sul, os fatores históricoinstitucionais de seu subsistema econômico fizeram com que, a partir da década de 1930, grande parte dos agentes optasse por um sistema de produção que reforçasse as atividades características locais precedentes (fundamentalmente capitalistas e manufatureiras). Dessa maneira, a elevada diversificação da região, promovida pelos imigrantes, evoluiu e tornou possível que ela se vinculasse dinamicamente ao padrão de acumulação nacional. Os conhecimentos técnicos e as escolhas dos agentes locais estavam de acordo com a nova dinâmica industrial brasileira, que teria início a partir da segunda metade do século XX, visto que existia, na região, capacidade de adaptação e competitividade para estágios mais avançados do processo de industrialização.

\section{Principais conclusões}

A partir da abordagem evolucionista, constata-se que o processo de desenvolvimento econômico é dependente de fatores institucionais e tecnológicos. Tais fatores são dependentes de eventos passados e, portanto, o processo é cumulativo, ou histórico. Variáveis como direitos de propriedade, conhecimento, cultura, ideologias políticas e aprendizagem tecnológica caracterizam-se por serem construídas, ou definidas, localmente, determinando o comportamento de firmas e das relações de poder na sociedade, bem como os custos de transação e transformação das atividades produtivas. Essas variáveis influenciam sobremaneira o processo de desenvolvimento econômico e fazem com este seja dependente da trajetória passada. A Figura 2 indica alguns elementos institucionalistas e neoschumpeterianos das duas regiões do Rio Grande do Sul que influenciaram amplamente a trajetória industrial de ambas no século XX.

(45) Segundo Licha e Oreiro (1998, p. 2), retornos crescentes são um fato comum em processos de escolha de formas organizacionais alternativas. O principal resultado é que, se a probabilidade de escolher uma ação aumenta com sua adoção, as primeiras adoções do processo podem levar a selecionar uma delas e excluir as outras. Com retornos crescentes, a eficiência histórica do procedimento selecionado não é garantida. Se, no começo do processo, uma ação melhora lentamente, ela pode ser excluída, e a estrutura de longo prazo pode ficar na opção inferior. A ineficiência resulta do fato de que os primeiros adotantes impõem externalidades aos que chegam depois, não existindo nenhum mecanismo que induza os agentes a explorar ações custosas no começo, mas atrativas para adotantes futuros. Com isso, um processo cujos resultados de longo prazo são decididos ao acaso, dependendo da história, pode ser ineficiente (Licha; Oreiro, 1998). 
Figura 2

Elementos institucionalistas e neoschumpeterianos do desempenho industrial das metades Norte e Sul do Rio Grande do Sul

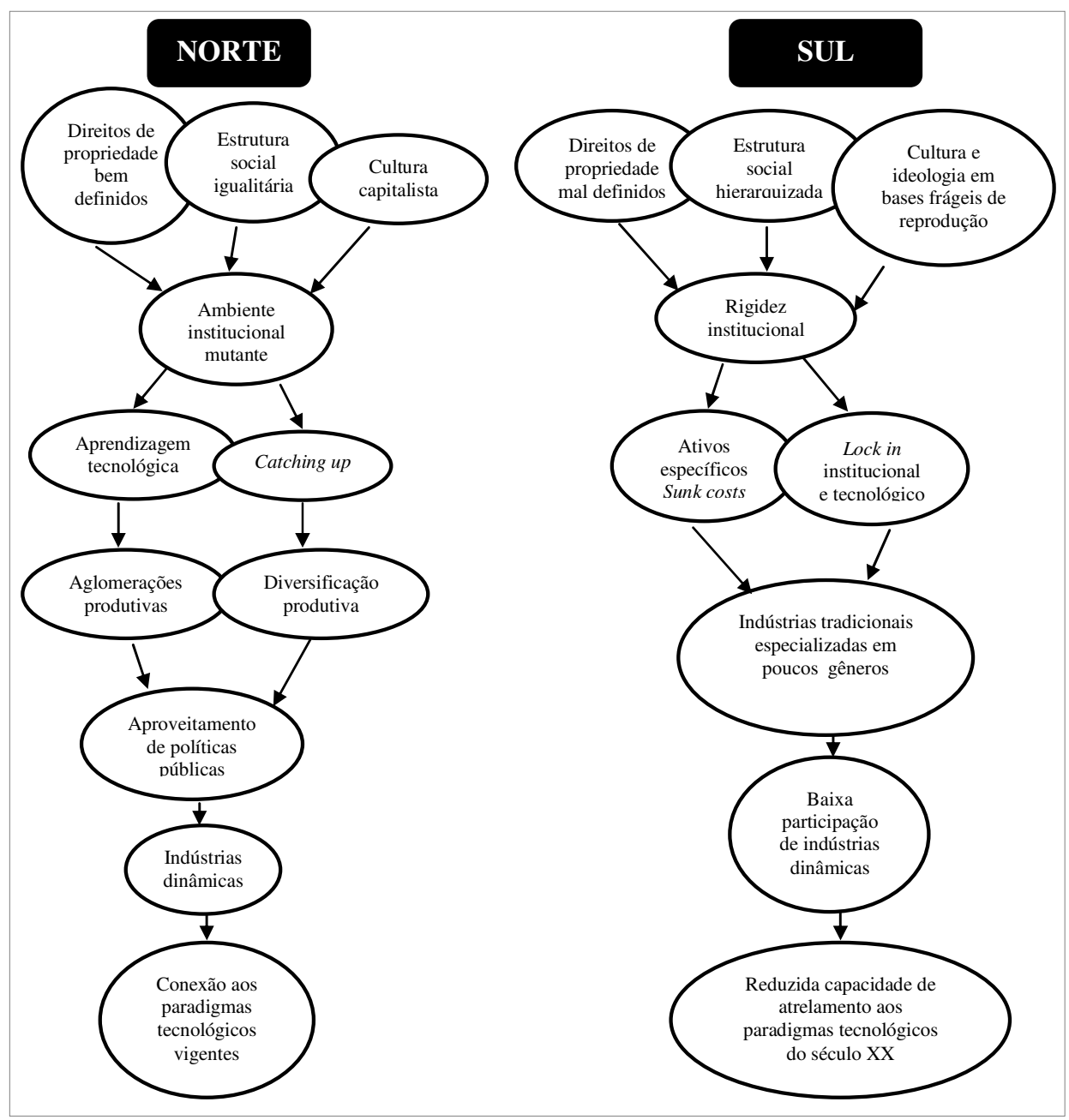

Fonte: Arend (2004).

$\mathrm{Na}$ definição dos direitos de propriedade de cada região estão as bases para o entendimento da problemática do desequilíbrio regional. Na região da Campanha, estruturou-se uma sociedade estratificada e patrimonialista, com elevada concentração da terra e defensora do monopólio para suas atividades. A elite dessa região dominou a esfera pública do Estado praticamente por um século (período imperial), beneficiando-se do privilégio de criar regras a seu favor. A escolha por atividades extremamente ligadas à pecuária levou à exclusão de outras opções, pois, com a existência de retornos crescentes, a classe hegemônica nesta região estava satisfeita em termos de acumulação de dinheiro; todavia, não estavam empreendidas em atividades que sinalizassem outras práticas capitalistas. 
As atividades desenvolvidas estavam relacionadas à pecuária, cujos processos de aprendizagem também influenciaram a trajetória industrial, pois a busca por novos conhecimentos reforçou a ideologia dos agentes, acabando por especializar a região em atividades primárias. A estrutura industrial atual da Metade Sul é resultado das experiências e dos investimentos realizados no passado e da capacidade adquirida em certos procedimentos e atividades. O efeito lock-in, assim, é evidente.

As instituições do Norte do Estado foram desenvolvidas em claro contraste com as características de desenvolvimento da região Sul. Nesses termos, criaram-se instituições que promoveram o desenvolvimento econômico e social. $\mathrm{Na}$ Metade Norte foram definidos direitos de propriedade mais eficientes, fundamentados, principalmente, na pequena propriedade, na estrutura social mais igualitária, na diversificação produtiva, nos conhecimentos técnicos e nos costumes e tradições capitalistas. Ambientes institucionais particulares, do início do século XX, contribuíram para que o eixo Porto Alegre - Caxias do Sul se transformasse no principal centro industrial do Estado e também para que a rudimentar indústria das principais cidades da Campanha, ao inserir-se na dinâmica capitalista, demonstrasse retraimento.

Tal consideração tornou-se evidente no período pós-1930, quando se ampliou o mercado interno brasileiro. Com o aumento da concorrência, os municípios da Metade Norte começaram a especializar-se em determinadas atividades industriais (couro e calçados, mecânica, metalurgia, material de transportes, vinhos, etc.), evidenciando-se aí o surgimento das aglomerações produtivas presentes, hoje, no Estado. A Metade Sul também aprofundou suas relações capitalistas, mas elas se restringiam ao beneficiamento primário (charqueadas e frigoríficos), cujos encadeamentos são extremamente limitados se comparados com os expressos pelas indústrias dinâmicas. Nesse momento, as regiões estabeleceram suas principais atividades produtivas em constituição de trajetórias de desenvolvimento distintas. O Norte diversificou e modernizou, em certa medida, sua estrutura industrial, e o Sul enraizou-se definitivamente na agropecuária. Apesar de haver fortes indicações na historiografia de que a economia da região Norte já se tornara mais expressiva que a da região Sul antes de 1930, a partir desse momento observa-se um maior aprofundamento do complexo colonial-imigrante em atividades industriais, resultante do maior estímulo do mercado interno brasileiro.

No momento de crise econômica dos anos 50 e 60 do século XX, com o papel do Governo Estadual, os investimentos somente poderiam direcionar-se para a região que apresentasse maiores externalidades positivas nos segmentos característicos do novo padrão de acumulação. Assim, o catching-up regional processado em relação ao padrão de produção nacional, fundado, sobretudo, no 
desenvolvimento das indústrias de bens de capital e bens de consumo duráveis, ocorreu na Metade Norte, consolidando-se a matriz industrial dessa região e, por consequência, a matriz industrial dinâmica do próprio Estado do Rio Grande do Sul. Atualmente, o Rio Grande do Sul possui o segundo PIB industrial do Brasil, considerada apenas a indústria de transformação. A produção industrial concentrase principalmente na região que, ao longo do século XX, soube adaptar-se aos impulsos da dinâmica de desenvolvimento econômico do Brasil.

\section{Bibliografia}

ABRAMOVAY, R. Desenvolvimento e instituições: a importância da explicação histórica. In: ARBIX, G.; ZILBOVICIUS, M.; ABRAMOVAY, R. Razões e ficções do desenvolvimento. São Paulo: Unesp/Edusp, 2001.

ACCURSO, C.; CANDAL, A.; VERAS, A. Análise do insuficiente desenvolvimento econômico do Rio Grande do Sul. Boletim da Comissão de Desenvolvimento Econômico, Porto Alegre, Assembléia Legislativa, n. 16, 1965.

ALBUQUERQUE, E. M. Notas sobre os determinantes tecnológicos do catching-up: uma introdução a discussão sobre o papel dos sistemas de inovação na periferia. Revista Estudos Econômicos, São Paulo, IPÊ, 1997.

ALMEIDA, P. F. C. A gestação das condições materiais da implantação da indústria gaúcha - 1870-1930. Ensaios FEE, Porto Alegre, v. 13, n. 2, 1992.

ALONSO, J. A. F. Análise do crescimento da região sul nas últimas décadas (1959-1990). In: ALONSO, J. A. F.; BENETTI, M. D.; BANDEIRA, P. S. Crescimento econômico da região sul do Rio Grande do Sul: causas e perspectivas. Porto Alegre: FEE, 1994.

O cenário regional gaúcho nos anos 90: convergência ou mais desigualdade?

Indicadores Econômicos FEE, Porto Alegre, v. 31, 2003.

; BANDEIRA, P. S. Considerações metodológicas sobre a divisão regional. In: ALONSO, J. A. F.; BENETTI, M. D.; BANDEIRA, P. S. Crescimento econômico da região sul do Rio Grande do Sul: causas e perspectivas. Porto Alegre: FEE, 1994.

AREND, Marcelo. Desenvolvimento e desequilíbrio industrial no Rio Grande do Sul: uma análise institucionalista e neo-schumpeteriana evolucionária. 2004. Dissertação (Mestrado)-UFSC/PPGE, Florianópolis, 2004.

ARAÚJO, H. J. V.; FISCHER, L. A. Para ler Raymundo Faoro. In: TARGA, L. R. P. (Org.). Breve inventário de temas do sul. Porto Alegre; Lajeado: UFRGS/FEE/Univates, 1998.

AZEVEDO, T. Italianos e gaúchos: os anos pioneiros da colonização italiana no Rio Grande do Sul. Porto Alegre: A Nação, 1975.

BANDEIRA, P. S. As raízes históricas do declínio da região sul. In: ALONSO, J. A. F.; BENETTI, M. D.; BANDEIRA, P. S. Crescimento econômico da região sul do Rio Grande do Sul: causas e perspectivas. Porto Alegre: FEE, 1994. 
Marcelo Arend / Silvio Antonio Ferraz Cario

BONI, L. A.; COSTA, R. Os italianos do Rio Grande do Sul. Porto Alegre: Escola Superior de Teologia São Lourenço de Brides/Universidade de Caxias/Correio Riograndense, 1984.

CARDOSO, F. H. Capitalismo e escravidão no Brasil meridional: o negro na sociedade escravocrata do Rio Grande do Sul. São Paulo: Difusão, 1977.

CASTILHOS, C. C.; PASSOS, C. (Coord.). Competitividade e inovação na indústria gaúcha. Porto Alegre; São Leopoldo: FEE/Unisinos, 1998.

CONCEIÇÃO, O. A. C. Instituições, crescimento e mudança na ótica institucionalista. Porto Alegre: FEE, 2002. (Teses).

DALMAZO, R. Planejamento estadual e acumulação no Rio Grande do Sul, 1940-1974. Porto Alegre: FEE, 1992.

DOSI, G. The nature of the innovative process. In: DOSI, G. et al. (Ed.). Technical change and economic theory. London: MERIT, 1988.

FAORO, R. Os donos do poder: formação do patronato político brasileiro. Porto Alegre: Editora Globo, 1975. 2 v.

FEE - Fundação de Economia e Estatística. Análise de indústria de transformação no Rio Grande do Sul. Porto Alegre: FEE, 1976 (Série 25 anos de economia gaúcha).

A produção gaúcha na economia nacional: uma análise da concorrência intercapitalista. T.1, Porto Alegre: FEE, 1983. Anuário Estatístico do Rio Grande do Sul. Porto Alegre: FEE, 1990. Anuário Estatístico do Rio Grande do Sul. Porto Alegre: FEE, 1995.

. Um século de população do Rio Grande do Sul 1900-2000. Porto Alegre: FEE, 2001.

FONSECA, P. C. D. RS: economia \& conflitos políticos na República Velha. Porto Alegre: Mercado Aberto, 1983.

FREEMAN, C.; PEREZ, C. Structural crisis of adjustment, business cycles and investment behaviour. In: DOSI, G. et al. Technical change and economy theory. London: Pinter Publishers, 1988.

FREITAS, D. Farrapos: uma rebelião federalista. In: FREITAS, D. et al. A revolução farropilha: história e interpretação. Porto Alegre: Mercado Aberto, 1985.

GRANOVETTER, M. Economic action and social structure: the problem of embeddedness. American Journal of Sociology, v. 91, p. 481-510, 1985.

HERRLEIN JR., R. Rio Grande do Sul, 1889-1930: um outro capitalismo no Brasil meridional. 2000. Tese (Doutorado em Economia)-Instituto de Economia, Universidade Estadual de Campinas, Campinas, 2000.

HODGSON, G. M. Economia e instituições: manifesto por uma economia institucionalista moderna. Oeiras: Celta Editora, 1994.

The approach of institutional economics. Journal of Economic Literature, v. 36, p. 166-192, Mar. 1998. 
IBGE. Censo Industrial do Rio Grande do Sul. Rio de Janeiro, 1960.

IBGE. Censo Industrial do Rio Grande do Sul. Rio de Janeiro, 1970.

IBGE. Censo Industrial do Rio Grande do Sul. Rio de Janeiro, 1980.

LANDO, A. M.; BARROS, E. C. A colonização alemã no Rio Grande do Sul: uma interpretação sociológica. Porto Alegre: Movimento, 1976.

LICHA, A. L; OREIRO, J. L. C. Retornos crescentes, path-dependence e organização das relações de trabalho: uma análise aplicada aos casos da Alemanha e do Reino Unido. In: ENCONTRO NACIONAL DE ECONOMIA POLÍTICA, 3, 1998, Niterói. Anais... Niterói: [s.n.], 1998.

LOVE, J. L. O regionalismo gaúcho e as origens da Revolução de 1930. São Paulo: Perspectiva, 1975.

MALERBA, F. Learning by firms and incremental technical change. The Economic Journal, v. 102, p. 845-859, Jul. 1992.

MARQUES, A. F. Evolução das charqueadas rio-grandenses. Porto Alegre: Martins Livreiro, 1990.

MELLO, J. M. C. O capitalismo tardio: contribuição à revisão crítica da formação e do desenvolvimento da economia brasileira. São Paulo: Brasiliense, 1982.

MERTZ, M. A burguesia industrial gaúcha e suas tentativas de organização: de sua origem a 1930. Ensaios FEE, Porto Alegre, v. 12, n. 2, p. 422-444, 1991.

MONASTERIO, L. M. Capital social e a região sul do Rio Grande do Sul. 2002. Tese (Doutorado em Economia)-Universidade Federal do Paraná, Curitiba, 2002.

EDUFPEL, 1998.

MULLER, G. A economia política gaúcha dos anos 30 aos 60. In: GONZAGA, S.; DACANAL, J. H. RS: economia e política. Porto Alegre: Mercado Aberto, 1979.

NELSON, R. R. Recent evolutionary theorizing about economic change. Journal of Economic Literature, v. 33, p. 48-90, Mar. 1995.

; WINTER, S. An evolutionary theory of economic change. Cambridge, Mass: Harvard University Press, 1982.

NORTH, D. Custos de transação, instituições e desempenho econômico. Rio de Janeiro: Instituto Liberal, 1994.

. Desempeño económico en el transcurso de los años. Conferência de Douglass C. North em Estocolmo, Suécia, 9 de dezembro de 1993, ao receber o Prêmio Nobel de Ciências Econômicas. Disponível em: http://www.eumed.net/cursecon/textos/northnobel.htm. Acesso em: 21 jan. 2004.

Instituciones, cambio institucional y desempeño económico. México: Fondo de Cultura Económica, 1995.

OLIVEIRA, F. de. Rio Grande do Sul: um novo nordeste? Rio de Janeiro: Civilização Brasileira, 1960. 
Marcelo Arend / Silvio Antonio Ferraz Cario

PESAVENTO, S. J. História da indústria sul-rio-grandense. Guaíba: Riocell, 1985.

A burguesia gaúcha: dominação do capital e disciplina do trabalho. Porto Alegre: Mercado Aberto, 1988.

Movimento, 1980.

República velha gaúcha: charqueadas, frigoríficos e criadores. Porto Alegre:

POSSAS, M. Em direção a um paradigma microdinâmico: a abordagem neoshumpeteriana. In: AMADEO, E. (Ed.). Ensaios sobre economia política moderna. São Paulo: Marco Zero, 1989.

REICHEL, H. J. A industrialização no Rio Grande do Sul na República Velha. In: GONZAGA, S.; DACANAL, J. H. RS: economia e política. Porto Alegre: Mercado Aberto, 1979.

ROCHE, J. A colonização alemã e o Rio Grande do Sul. Porto Alegre: Globo, 1969.

SCHUMPETER, J. A. Teoria do desenvolvimento econômico: uma investigação sobre lucros, capital, crédito, juro e o ciclo econômico. São Paulo: Nova Cultural, 1988.

STRACHMAN, E. Instituições: uma caracterização crítica. Revista da ANPEC, n. 1, jan./jun. 2002.

SUZIGAN, W. Indústria brasileira: origens e desenvolvimento. São Paulo: Brasiliense, 1986.

TARGA, L. R. P. A fundação do estado burguês no Rio Grande do Sul (1891-1913). In: CONGRESSO DE HISTÓRIA ECONÔMICA, 5., 2003, Caxambú. Anais... Caxambú, MG: ABPHE, 2003.

. Elites regionais e formas de dominação. In: TARGA, L. R. P. (Org.). Breve inventário de temas do sul. Porto Alegre; Lajeado: UFRGS/FEE/Univates, 1998.

. Gaúchos e paulistas: dez escritos de história regional comparada. Porto Alegre: FEE, 1996.

; SILVA, E. N. S. A exclusão política da oligarquia tradicional gaúcha. In: PRIMEIRAS JORNADAS DE HISTÓRIA REGIONAL COMPARADA, 2000, Porto Alegre. Anais... Porto Alegre, RS: FEE, 2000.

TEJO, L. A indústria rio-grandense em função da economia nacional. Porto Alegre: Globo, 1939.

URBIM, C. Os farrapos. Porto Alegre: Zero Hora Editora Jornalística, 2003.

UTTERBACK, J. M. Dominando a dinâmica da inovação. Rio de Janeiro: QualityMark, 1996.

VEBLEN, T. A teoria da classe ociosa: um estudo econômico das instituições. São Paulo: Livraria Pioneira Editora, 1965.

WILLIAMSON, O. E. The economic institutions of capitalism. New York: The Free Press, 1985. 